Canadian Science Publishing

Canadian Journal of Earth Sciences Revue canadienne des sciences de la Terre

\title{
A Multi-century Estimate of Suspended Sediment Yield from Lillooet Lake, Southern Coast Mountains, Canada
}

\begin{tabular}{|r|l|}
\hline Journal: & Canadian Journal of Earth Sciences \\
\hline Manuscript ID & cjes-2017-0025.R1 \\
\hline Manuscript Type: & Article \\
\hline Date Submitted by the Author: & 29 -Jun-2017 \\
\hline $\begin{array}{r}\text { Complete List of Authors: } \\
\text { Is the invited manuscript for } \\
\text { consideration in a Special } \\
\text { Issue? : }\end{array}$ & $\begin{array}{l}\text { Nenounos, Brian; Geography Program } \\
\text { Clague, John J.; Dept of Earth Sciences, }\end{array}$ \\
\hline Keyword: & Lillooet River, British Columbia, sediment yield, varves, glacial history \\
\hline
\end{tabular}


1 Title:

2 A Multi-century Estimate of Suspended Sediment Yield from Lillooet Lake, Southern Coast Mountains,

3 Canada

4

5

6 Authors:

$7 \quad$ Marit Heideman ${ }^{\mathrm{a}}$ (corresponding author)

8 Brian Menounos ${ }^{b}$

9 John J. Clague ${ }^{\text {a }}$

10

$11{ }^{\mathrm{a}}$ Department of Earth Sciences

12 Simon Fraser University

138888 University Drive

14 Burnaby, BC, V5A 1S6, Canada

15 mheidema@sfu.ca; jclague@sfu.ca

16

$17{ }^{\mathrm{b}}$ Geography Program and Natural Resources and Environmental Studies Institute

18 University of Northern British Columbia

193333 University Way

20 Prince George, BC, V2N 4Z9, Canada

21 menounos@unbc.ca

22 
A multi-century estimate of suspended sediment yield from Lillooet Lake

23 A Multi-century Estimate of Suspended Sediment Yield from Lillooet Lake, Southern Coast Mountains,

24 Canada

26 Marit Heideman, Brian Menounos, John J. Clague

\section{Abstract}

We use annually laminated lake sediments to estimate suspended sediment yield for a $3850 \mathrm{~km}^{2}$ montane catchment in the British Columbia Coast Mountains. Sediment yield over the past 369 years averages $213 \pm 38 \mathrm{Mg} \mathrm{km}^{-2} \mathrm{a}^{-1}$. Sediment yield increases to $285 \pm 50 \mathrm{Mg} \mathrm{km}^{-2} \mathrm{a}^{-1}$ during the first half of the twentieth century and declines thereafter. The frequency of high-yield events during the 369-year period is

33 irregular: 11 of the 34 events occur in the early part of the twentieth century, a time when glaciers in the

34 watershed underwent major retreat. We fitted a Generalized Extreme Value (GEV) model to estimate 35 quantiles of the sediment yield distribution, and we used epoch analysis to examine persistence in sediment 36 yield following 34 of the largest events. Persistence is greatest for the most extreme events; it is more 37 variable for events that recur, on average, every 10 to 25 years. Our results indicate that sediment yield is

38 linked to long-term changes in sediment supply to the lake. The results of this study extend earlier sediment 39 yield estimates and improve understanding of linkages to watershed geomorphology, recent glacier retreat, 40 and landslides in the Lillooet River watershed.

\section{Keywords:}

43 Lillooet River, British Columbia, sediment yield, varves, glacial history, landslides 
A multi-century estimate of suspended sediment yield from Lillooet Lake

\section{1. Introduction}

45 Specific sediment yield is the amount of sediment that leaves a watershed during a specified period, 46 typically days or years; as opposed to basin-wide total yield, it is measured as mass per unit area per unit

47 time (Onstad, 1984; Schiefer et al., 2010). Sediment yield studies are performed to assess sediment sources, 48 production, transport, and storage within watersheds. These studies provide valuable information on the

49 influences of glacier cover (Desloges, 1994), hydrology and climate (Lamoureux, 2002; Menounos et al., 50 2006), land-use changes (O'Hara et al., 1993; Zolitschka, 1998), landslides (Koi et al., 2008), and other

51 landscape disturbances (Major et al., 2000) on long-term sediment export from mountain catchments, as

52 well as the complex connectivity between sedimentary and geomorphic processes (Wohl et al., 2017).

53 Lacustrine sediments are ideal proxies of long-term suspended sediment yield because lakes trap

54 clastic sediments derived from the upstream watershed (e.g., Zolitschka, 1998). Annually laminated

55 (varved) lacustrine records offer an additional advantage because they provide insight into hydroclimatic

56 and depositional conditions in the basin with annual to sub-annual resolution (Desloges and Gilbert, 1994;

57 Lamoureux, 2000). Several studies in the Canadian Cordillera have used varved sediments to estimate

58 suspended sediment yield in proglacial lakes (Desloges, 1994; Menounos et al., 2006; Schiefer et al., 59 2010).

Previous research documents sedimentation and sediment yield in the Lillooet River watershed, a

$613850 \mathrm{~km}^{2}$ mountain watershed in the southern Coast Mountains of British Columbia, Canada (Figure 1).

62 Gilbert $(1972,1973,1975)$ inferred sedimentary and lacustrine processes responsible for the distribution

63 and character of sediments in Lillooet Lake. He estimated average total clastic sediment yield in the

64 Lillooet River watershed to be $334 \mathrm{Mg} \mathrm{km}^{-2} \mathrm{a}^{-1}$. Gilbert (1975) further showed that the lake sediments are

65 annually laminated (varved) and that varve thickness is related to Lillooet River discharge. Jordan and 
A multi-century estimate of suspended sediment yield from Lillooet Lake

Slaymaker (1991) used a sediment budget approach to determine sources, storage, and yield of sediment in the Lillooet River watershed. They found that Holocene sediment input is highly episodic and that colluvial and glacial sediment sources are likely underestimated. Recurrent mass movements off the Mount Meager volcanic complex (Friele and Clague, 2004), changes in glacier cover (Desloges and Gilbert, 1994), and the formation of Silt Lake in the forefield of Lillooet Glacier at the head of the watershed (Schiefer and Gilbert, 2008) could explain the imbalance that Jordan and Slaymaker (1991) found in their sediment budget.

In this paper, we report on a multi-century record of specific suspended sediment yield from the Lillooet River watershed based on analysis of cores collected from Lillooet Lake. Our objective is to provide, on a timescale of hundreds of years, a better understanding of (1) changes in sediment export from a mountain watershed in which sediment production is dominated by changes in glacier cover, landslides, and floods, and (2) the connectivity between sediment sources and processes and sediment accumulation in the lake. Years with exceptionally high yields are identified, and we attempt to explain conditions that could account for these anomalous years. We also consider annual and decadal impacts of glacier activity and known pre-historic and historic landslides in the watershed on the production and delivery of suspended sediment to Lillooet Lake. The results of this study provide a long-term perspective of the importance of landslides and glacier cover on specific sediment yield in the Canadian Cordillera.

\section{Study site and methods}

Lillooet Lake is an oligotrophic dimictic lake with a length of $22 \mathrm{~km}$, a width up to $2 \mathrm{~km}$, and a maximum depth of $137 \mathrm{~m}$ (Figure 1; Desloges and Gilbert, 1994). About 14\% of the watershed is covered by glacier ice and persistent snow. Peaks in the watershed reach up to $2700 \mathrm{~m}$ above sea level (asl), 
A multi-century estimate of suspended sediment yield from Lillooet Lake

whereas the broad flat floor of Lillooet River valley ranges from about $200 \mathrm{~m}$ asl at Lillooet Lake to $820 \mathrm{~m}$ asl at the toe of Lillooet Glacier.

The climate station at Pemberton Airport receives, on average, $890 \mathrm{~mm}$ of water-equivalent precipitation annually, mainly during autumn and winter (Environment Canada, 2011). Higher elevations in the watershed likely receive over $3000 \mathrm{~mm}$ water-equivalent precipitation each year (Pacific Climate Impacts Consortium, 2016).

Lillooet River is the dominant source of water and sediment to Lillooet Lake. The river heads at Lillooet Glacier about $95 \mathrm{~km}$ northwest of Lillooet Lake. Silt Lake, a large proglacial lake, lies about $2 \mathrm{~km}$ beyond the present terminus of Lillooet Glacier. The principle tributaries of Lillooet River are Meager Creek, and Ryan, Birkenhead, and Green rivers (Figure 1). Mean annual discharge of Lillooet River is 126 $\mathrm{m}^{3} \mathrm{~s}^{-1}$ based on a record of discharge that exceeds 90 years. In a typical year, the river experiences a nival melt peak of $400-600 \mathrm{~m}^{3} \mathrm{~s}^{-1}$ in June and a similar-size peak related to snow and glacier ice melt in July (Environment Canada, 2010). Floods with peak discharge up to $1370 \mathrm{~m}^{3} \mathrm{~s}^{-1}$ (in 2003) occur in the fall during intense rain or rain-on-snow storms.

Most of the sediment deposited in Lillooet Lake is delivered by Lillooet River (Desloges and Gilbert, 1994). Concentrations of suspended sediment discharged into Lillooet Lake vary throughout the year. In winter, when discharge is lowest, suspended sediment concentrations are as low as $5 \mathrm{mg} \mathrm{l}^{-1}$, whereas during nival and glacial melt in late spring and summer they are 600-800 $\mathrm{mg} \mathrm{l}^{-1}$, and during floods they are over $1200 \mathrm{mg} \mathrm{l}^{-1}$ (Gilbert, 1975; Hodder, 2009).

Lillooet River drains mainly Mesozoic granitic and metamorphic rocks (Read, 1979). However, the Mount Meager Volcanic Complex, located in the upper part of the watershed (Figure 1), comprises andesitic and dacitic lavas and pyroclastic rocks of Plio-Pleistocene and Holocene age. The most recent 
A multi-century estimate of suspended sediment yield from Lillooet Lake

110 eruption from this massif happened about 2400 years ago (Clague et al., 1995). Some of the volcanic rocks

111 have been hydrothermally altered and are highly susceptible to landslides (Mokievsky-Zubok, 1977; Read,

112 1990; Friele and Clague, 2004; Guthrie et al., 2012). Landslides are common on the flanks of the volcanic

113 massif and range from rare flank collapses with volumes of hundreds of million cubic metres (Friele and

114 Clague, 2004) to small debris flows that occur every year during hot weather or rain. The most recent large

115 landslide happened in 2010 in the headwaters of Capricorn Creek, a tributary of Meager Creek (Roche et

116 al., 2011; Guthrie et al., 2012). This landslide delivered about $48.5 \times 10^{6} \mathrm{~m}^{3}$ of debris to the valleys of

117 Meager Creek and Lillooet River and stemmed the flow of both streams for a short time.

118 We collected three percussion cores and nine vibracores from Lillooet Lake during the summers of

1192005 and 2006 (Figure 1). The cores were collected throughout the lake basin in water depths ranging from

12078 to $128 \mathrm{~m}$; the cores have lengths that range from $1.8 \mathrm{~m}$ to $11.1 \mathrm{~m}$ (limitations in the results due to core

121 location are discussed below). We split, logged, and photographed the cores and sampled them at a $10-\mathrm{cm}$

122 interval for bulk density and grain size analysis. Desloges and Gilbert (1994) and Menounos et al. (2005)

123 found low $(<1 \%)$ concentrations of organic matter in their cores from the lake, and so we use $5 \%$ as a

124 conservative measure of organic content. We identified and digitally measured silt-clay couplets, which

125 Gilbert (1973, 1975), Desloges and Gilbert (1994), and Heideman et al. (2015) demonstrated to be varves,

126 with a resolution of $0.1 \mathrm{~mm}$ using Gimp2 (2012) software to determine sedimentation rates (SR).

127 To estimate sediment yield, we first calculated the average sedimentation rate $\left(S R_{i}\right)$ in each core $(i)$ as

128 the product of the accumulation rate $\left(A R_{i}\right)$ and dry density $\left(D D_{i}\right)$ :

129

$$
S R_{i}\left(k g m^{-2} a^{-1}\right)=A R_{i}\left(m a^{-1}\right) \times D D_{i}\left(k g m^{-3}\right)
$$

130 Thiessen (Voroni) polygons were used to represent contributing areas for a given core. We computed 131 sediment mass $\left(\mathrm{M}_{\mathrm{i}}\right)$ by multiplying sedimentation rates by core polygon area $($ Area $)$ : 
A multi-century estimate of suspended sediment yield from Lillooet Lake

132

133

134

135

136

137

138

139

140

$$
M_{i}\left(k g a^{-1}\right)=S R_{i}\left(k g m^{-2} a^{-1}\right) \times \operatorname{Area}_{i}\left(m^{2}\right)
$$

To build the varve chronology, we identified and traced distinctive varves from core to core; the ones that were disturbed were excluded from sediment yield calculations. For these years, we estimated sediment yield by assuming that sedimentation rates in neighbouring cores are representative of those in the excluded core and by thus merging the Thiessen polygon with its closest neighbour(s).

We then calculated total sediment mass for each year by summing the masses of contributing cores for that year. Finally, we calculated suspended sediment yield $\left(Y_{y}\right)$ for each year $(y)$ by dividing the total sediment mass $\left(M_{t o t}\right)$ by the catchment area $(C A)$ :

$$
Y_{y}\left(k g k m^{-2} a^{-1}\right)=M_{t o t}\left(k g a^{-1}\right) / C A\left(k m^{2}\right)
$$

Sediment yields are reported as megagrams $\left(\mathrm{Mg} \mathrm{km}^{-2} \mathrm{a}^{-1}\right)$ in this study. Absolute sediment yield estimates are indicated by ' $\mathrm{Y}$ '. Recurrence intervals of specified sediment yields are reported, for example as $\mathrm{Y}_{10}$ or $\mathrm{Y}_{10-25}$, denoting sediment yields with, respectively, recurrence intervals of once every ten years and once every ten to 25 years.

Errors in sediment yield values arise from each of the above-mentioned steps in the procedure: varve thickness measurements, dry density estimates, and Thiessen polygons that assume an area of equal sedimentation rates around each core. Error is also introduced from our estimate of organic matter and from the limited number of cores contributing to the chronology.

$$
\text { To estimate varve thickness error, we re-measured five to eight consecutive varves in undisturbed, }
$$
well correlated sections of each core. The average difference in measurements is $6.1 \%$, which we took to be the varve thickness error. Maximum errors stemming from missing and false varves are 1.61\% (Heideman et al., 2015), and we include this error term in our sediment yield uncertainty estimates. We did 
A multi-century estimate of suspended sediment yield from Lillooet Lake

153

154

155

not replicate dry density measurements; rather we used the standard deviation for each core $( \pm 1 \sigma)$ to derive an error estimate for this variable. The resulting estimate of error in dry density measurements is $11.2 \%$, and our uncertainty (standard deviation) for the organic content of the sediments is $10.9 \%$.

We estimated error related to the number of cores contributing to the calculation of total sediment yield for the period AD 1629-1997 by comparing the difference in yield between estimates based on 10 or 11 cores (i.e. the maximum number of cores contributing to the chronology in a given year) and estimates based on the five cores that make up the chronology up to AD 1629 . This error is $5.5 \%$.

The use of Thiessen polygons assumes that sediment deposition is spatially uniform throughout each polygon. The polygons, however, underestimate sedimentation in places like the delta front, the lake shoreline, and steep slopes on the lake bottom (Gilbert, 1975; Jordan and Slaymaker, 1991). Schiefer (2006), for example, estimated that deltaic sediments in nearby Green Lake cover approximately $10 \%$ of the total lake-bottom area and that massive and weakly laminated deposits constitute about 13\% and 19\%, respectively, of the lake bottom. Varved sediments in Green Lake are thus present on only $58 \%$ of the total lake floor. Although Green Lake and Lillooet Lake differ considerably in size $\left(2.0 \mathrm{~km}^{2}\right.$ vs. $\left.35 \mathrm{~km}^{2}\right)$ and depth (44 m vs. $137 \mathrm{~m}$ ), both have similar bathymetries (Schiefer and Klinkenberg, 2004). Previous studies (Gilbert, 1973, 1975; Gilbert and Desloges, 1994) offer useful information on bottom sediments in Lillooet Lake, but do not provide a lake-wide quantitative spatial inventory. Weakly laminated sediments are recorded in proximal cores C and D in Lillooet Lake (Figure 1). Sedimentation north of core D (Figure 1) is likely underestimated and occurs over nearly $25 \%$ of the total area of the lake bottom. Because the number of cores used in this study is limited and no cores were taken on the delta front, it is not possible to precisely quantify the error related to spatial differences in sedimentation. In-lake sedimentation processes (e.g., lake stratification, sediment movement in overflows and underflows, water column turn-over, and 
A multi-century estimate of suspended sediment yield from Lillooet Lake

175 flocculation [Gilbert, 1975; Hodder, 2009]), and the timing of floods can also affect sediment distribution 176 and accumulation in the lake.

177 We adopt standard error propagation methods that are suitable for measurements of terms found in 178 equations 3.2 and 3.3 (Taylor, 1982). Total error in suspended sediment yield from errors in dry density, 179 varve thickness, organic content, varve counting error, and the number of cores contributing to the yield is 180 estimated to be $\pm 17.7 \%$.

\section{3. Results}

\subsection{Sediment yield statistics}

The varve sequence retrieved from Lillooet Lake extends from AD 1179 to 2004 (Heideman et al.,

185 2015). Sediment yield appears to be below the long-term average from the beginning of the record to around AD 1629 (Figure 2). The early part of the record, however, is based on only two cores (A and B),

187 both of which originate from the distal basin. The distal cores in Lillooet Lake have lower sedimentation 188 rates than cores from the proximal basin. To test whether this bias could be removed, we regressed the 189 average sediment mass accumulation in cores A and B (the cores with the longest records) with the total 190 basin yield for the period AD 1629-2004. The explained variance is poor $\left(\mathrm{r}^{2}=0.044, \mathrm{p}<0.05\right)$, which 191 indicates that sedimentation at the two distal cores sites is not representative of total sediment yield in the 192 basin. We therefore excluded years prior to AD 1629 from further analysis. Likewise, the sediment yield 193 record for the period 1998-2004 is based on one to three cores and was similarly excluded from further 194 analysis.

195 Sediment yield for the period AD 1629-1997 ranges from 74 to $672 \mathrm{Mg} \mathrm{km}^{-2} \mathrm{a}^{-1}$; the long-term 196 average value is $213 \pm 38 \mathrm{Mg} \mathrm{km}^{-2} \mathrm{a}^{-1}$ (Table 1, Figure 3). Minimum and maximum values for the 
A multi-century estimate of suspended sediment yield from Lillooet Lake

197

twentieth century are similar to the long-term values, $77 \mathrm{Mg} \mathrm{km}^{-2} \mathrm{a}^{-1}$ (AD 1916) and $659 \mathrm{Mg} \mathrm{km}^{-2} \mathrm{a}^{-1}$ (AD 1906), but the average for this period is $11 \%$ greater $\left(234 \pm 42 \mathrm{Mg} \mathrm{km}^{-2} \mathrm{a}^{-1}\right)$ than the long-term average and is the highest centennial average for the period of record. In addition, the average for the first half of the twentieth century (AD 1900-1945) is much higher than the average for the second half of the century (AD 1946-1997): $285 \pm 50$ vs. $183 \pm 32 \mathrm{Mg} \mathrm{km}^{-2} \mathrm{a}^{-1}$.

We calculated general descriptive statistics for the sediment yield data for the period AD 1629-1997 (Table 1). The statistics imply a strongly non-normal distribution of sediment yield estimates, with the maximum sediment yield estimate exceeding the mean by over three times. Extreme value distributions, such as Gumbel, Fréchet, and Weibull, are typically used in paleoflood hydrology studies (e.g. Hosking and Wallis, 1986) to estimate the upper quantiles of a probability distribution. We therefore fitted a generalized extreme value model (Jenkinson, 1955) - a flexible model that estimates the three parameters determining the Gumbel, Fréchet, and Weibull distributions — to estimate yield quantiles and return intervals for outliers in the AD 1629-1997 sediment yield chronology. The resulting GEV model had a resulting shape parameter of $\mathrm{k}>0$ and can thus be classified as a GEV type II or Fréchet-type distribution (c.f. Lamoureux, 2002).

We determined recurrence times of peaks in the sediment yield record using a generalized extreme value model (GEV type II). Years of high sediment yield ( $\left.>\mathrm{Y}_{10}\right)$ are unevenly distributed in the 369-year record (Figures 4 and 5): 13 of the 34 peaks are in the twentieth century (Table 2). Peaks in sediment yield with an average return period greater than once every 10 years exceed the AD 1629-1997 mean yield by 1.6 to 3.1 times (Figure 4). Peaks in sediment yield with an average return period of more than 25 years $\left(>Y_{25}\right)$ cluster around AD 1776-1825 and AD 1906-1931; the intervening period lacks such extremes and includes only five peaks with an average return period ranging from 10 to 25 years $\left(\mathrm{Y}_{10-25}\right)$. Another 
A multi-century estimate of suspended sediment yield from Lillooet Lake

219 striking characteristic of the AD 1629-1997 sediment yield record is the above-average yield from around 220 AD 1920 to 1946, but much lower yields after AD 1946.

\subsection{Long-term sediment-yield departures}

Cumulative sediment-yield departures demonstrate the effect of high-yield years on sediment delivery in subsequent years (Lamoureux, 2002). The sediment yield record for Lillooet Lake has five

224 periods with negative trends: AD 1629-1696, 1729-1768, 1777-1792, 1826-1881, and 1945-1997 (Figure

225 5). The onset of each of four subsequent positive-trending periods (AD 1697-1728, 1769-1776, 1793-1825, 226 1882-1944), however, is not a high-yield $\left(>Y_{10}\right)$ year. Instead, high-yield years $\left(>Y_{10}\right)$ typically occur three 227 to five years following the start of a positive-trending period. yields with return periods greater than 50 years only occur during positive-trending periods.

In many instances, high-yield years are 'stand-alone' events. Some of these stand-alone years are immediately followed by a negative trend in cumulative sediment yield, for example after AD 1647, 1661, 233 and 1991. In contrast, a positive trend for two decades follows the high-yield years of AD 1712, 1713, and 234 AD 1921.

Two of the highest yield years, both of which have estimated return periods greater than 100 years 236 (AD 1776, 1825), are separated by only 49 years and occur at the end of a period of positive-trending 237 years. After AD 1825, cumulative sediment yield has a negative trend that persists until AD 1881, followed 238 by a 63-year period with a positive trend until AD 1946. Twelve high-yield events $\left(>Y_{10}\right)$ occur during the 239 period AD 1881-1946, of which three have return periods greater than 100 years. 
A multi-century estimate of suspended sediment yield from Lillooet Lake

These results show that the highest yield years are not necessarily followed by long periods (e.g. more than a decade) of above-average yields. Only two smaller yield years (i.e. AD 1712 and 1713)

242 precede intervals of above-average sediment yield spanning about three decades (Figure 5).

\section{3}

244

245

246

247

248

249

250

251

252

253

254

\subsection{Sediment yield trends following high-yield years}

The Lillooet Lake sediment yield record includes 34 years with estimated return periods greater than 10 years (Table 2). Examination of cumulative departures in the 30 years immediately after each high-yield year $\left(>Y_{10}\right)$ reveals highly variable sedimentation patterns (Figures 7 and 8 ). Two years with the highest yields ( $>\mathrm{Y}_{100}$; AD 1921 and 1931) are followed by prolonged periods of above-average yield (Figure 6a). The high yields of AD 1921 and 1931 are followed by above-average yields in 1936 and 1940. The average trends in the $\mathrm{Y}_{50-100}$ and $\mathrm{Y}_{25-50}$ groups (Figure $6 \mathrm{~b}$ and $6 \mathrm{c}$ ) are positive for the first 12 and 10 years, respectively. Individual signals of years AD $1823\left(\mathrm{Y}_{50-100}\right), 1774\left(\mathrm{Y}_{25-50}\right)$, and $1936\left(\mathrm{Y}_{25-50}\right)$ are influenced by much larger events two to four years later (i.e. AD 1825, 1776, and 1940, respectively). The common pattern in the $\mathrm{Y}_{10-25}$ group is above-average sediment yield immediately after event years (Figure 7), but there are many exceptions. The events in the seventeenth century are noteworthy: all show a negative trend following the high-yield year. The other centuries show more variable trends after high yield events.

\subsection{Persistence of high-yield years}

To further assess the impact of high-yield years on subsequent sedimentation in Lillooet Lake, we superposed the years in each quantile group. For each high-yield year, we calculated the deviation from the 40-year mean for 10 years prior to and 30 years after each event (Panofsky and Brier, 1958; Lamoureux, 2002). The significance of high-yield years $\left(>Y_{10}\right)$ was tested using the 'sea' command in the dplR package of the statistical program $\mathrm{R}$, in which randomly selected years were bootstrap resampled to determine the significance of departures from the mean. No persistence of high-yield years is evident over the entire 
A multi-century estimate of suspended sediment yield from Lillooet Lake

262 length of the record, but weak relations are apparent for specific sediment yield groups (i.e. $>\mathrm{Y}_{10}, \mathrm{Y}_{25-50}$, $\left.263 \mathrm{Y}_{50-100}, \mathrm{Y}_{100}\right)$.

264 All high-yield years $\left(>\mathrm{Y}_{10}\right)$ have significant $(\mathrm{p}<0.05)$ departures from the mean. Persistence is 265 evident in two of the first five years immediately after all 34 events (Figures 8b and 8c), although 266 deviations from the mean are small $\left(<50 \mathrm{Mg} \mathrm{km}^{-2} \mathrm{a}^{-1}\right)$. For years with a return period greater than 100 years 267 (Figure 8a), the first year after the event has above-average sediment yield, but that year is followed by 268 four years with below-average yields. In the case of the $\mathrm{Y}_{50-100}$ group, positive deviations from the mean 269 are evident in four of the first five years after the high-yield year, but subsequent years show more negative 270 deviations from the mean than positive deviations. The $\mathrm{Y}_{25-50}$ group (Figure 8c) shows an initial positive 271 deviation from the mean, followed by mainly below-average yields after four years. Similarly, the $\mathrm{Y}_{10-25}$ 272 group (Figure 8d) has an initial positive deviation in the first year, with slightly positive and negative 273 deviations after that.

274 The $\mathrm{Y}_{50-100}$ and $\mathrm{Y}_{25-50}$ groups display above-average yields in, respectively, five and eight of the ten 275 years prior to the high-yield year. The other two groups have more negative years leading up to the high276 yield year.

277 Persistence in high-sediment yields is more pronounced in the twentieth century in the $\mathrm{Y}_{50-100}$ and $278 Y_{25-50}$ quantile groups than in the other groups. However, 13 of the 34 high-yield years are in the twentieth 279 century, and 11 of those 13 years are in the period AD 1900-1946, which is a period of above-average 280 sedimentation (Figure 3). It is therefore difficult to draw conclusions about persistence of sediment yield in 281 the twentieth century, because high-yield events $\left(>Y_{10}\right)$ occur on average every 4.2 years in the first 46 282 years of the century, and any persistence in the system is masked by subsequent, possibly unrelated, high283 yield events. In comparison to the persistence pattern for the entire 369-year record (Figure 8), there are a 
A multi-century estimate of suspended sediment yield from Lillooet Lake

284 larger number of years with positive deviations in the twentieth century (Figure 9), but this too can be 285 attributed to the frequency of high-yield years in the first half of the century.

\section{Discussion}

\subsection{Comparisons to other sediment yield studies in western Canada}

The long-term (AD 1629-1997) average suspended sediment yield estimate $\left(213 \pm 38 \mathrm{Mg} \mathrm{km}^{-2} \mathrm{a}^{-1}\right)$ for the period AD 1629-1997 (Table 3) is similar to the estimate of Desloges and Gilbert (1994) based on their study of Lillooet Lake, but less than those of Slaymaker (1972) and Gilbert (1973).

Church and Slaymaker (1989) argue that sediment yield in British Columbia increases as a function

293 of watershed area in catchments up to $3 \times 10^{4} \mathrm{~km}^{2}$ in area. This conclusion is supported by sediment yield 294 estimates derived from cores extracted from Harrison Lake (Desloges and Gilbert, 1991), Green Lake 295 (Menounos et al., 2006; Schiefer et al., 2010), Chilko Lake (Desloges and Gilbert, 1998), Bowser Lake 296 (Gilbert et al., 1997), Moose Lake (Desloges and Gilbert, 1995), and smaller lakes in the Canadian 297 Cordillera (Desloges, 1994; Schiefer et al., 2001; Schiefer and Gilbert, 2008). Long-term suspended 298 sediment yield estimates derived from the Lillooet Lake data (Figure 10) fall within the expected sediment 299 yield pattern in British Columbia.

Sediment yield in the Lillooet River watershed in the twentieth century was likely affected by many 301 events, notably landslides, floods, glacier retreat, the formation of Silt Lake, river engineering, and land302 use changes in the watershed. In comparison, the watershed of nearby Green Lake before the establishment 303 of the Whistler ski resort in the 1960s was largely undisturbed and was not subject to river straightening or 304 dyking (Menounos et al., 2006). Sediment yield in the Green Lake watershed before the 1960s thus reflects 305 more natural conditions. Suspended sediment yield, as derived from varved sediments, in Green Lake 
A multi-century estimate of suspended sediment yield from Lillooet Lake

306

307

308

309

310

311

312

313

314

315

316

317

318

319

320

321

322

323

324

325

326

327

during the period 1931-1991 is 10\% higher than during the past 3000 years (Menounos et al., 2006): ca. 76 $\mathrm{Mg} \mathrm{km}^{-2} \mathrm{a}^{-1}$ vs. 69.4 $\mathrm{Mg} \mathrm{km}^{-2} \mathrm{a}^{-1}$. Menounos et al. (2006) attributed the higher sediment yield during the twentieth century to increased sedimentation accompanying retreat of glaciers between 1935 and 1945 , although human disturbances in the watershed between about 1960 and 1991 may also have played a role. Schiefer et al. (2010) extended the work of Menounos et al. (2006) in Green Lake. They studied lake sediment cores, delta progradation, and solute transport, and concluded that the average annual total sediment yield since the mid-1900s has been $320 \pm 40 \mathrm{Mg} \mathrm{km}^{-2} \mathrm{a}^{-1}$, of which about $35 \%$ is suspended load, $50 \%$ is bedload, and $15 \%$ is dissolved load. The ratios of the three components of sediment yield, however, differ significantly on a decadal time scale, which could have important consequences if short-term values are used to estimate long-term sediment yields. Similarly, Loso et al. (2004) reported that suspended sediment is less than $20 \%$ of the total clastic sediment discharge into Alaskan proglacial Iceberg Lake. If the sediment yield fractions for Green Lake are applicable to Lillooet Lake, and assuming constant ratios through time, total clastic sediment yield to Lillooet Lake would be $671 \pm 119 \mathrm{Mg} \mathrm{km}^{-2} \mathrm{a}^{-1}$ during the twentieth century and $612 \pm 108 \mathrm{Mg} \mathrm{km}^{-2} \mathrm{a}^{-1}$ for the period AD 1629-1997. However, these estimates should be viewed with care given the differences in the area and hypsometry of the two watersheds, the ratio of lake area to catchment area, and possibly other factors. Studies by Schiefer et al. (2010) and Loso et al. (2004) indicate that estimates of total clastic sediment yield based solely on the suspended sediment fraction may be misleading in some environments.

Considerable reductions in sediment yield in the second half of the twentieth century characterize icemarginal Ape Lake in the central Coast Mountains and proglacial Berg Lake (Desloges, 1994) and Hector Lake (Leonard, 1997) in the Rocky Mountains. Varve-based sediment yield records from the first two lakes show declining sedimentation throughout the twentieth century, with a further abrupt decrease after AD 
A multi-century estimate of suspended sediment yield from Lillooet Lake

328

329

330

331

332

333

\section{4}

335

336

337

338

339

340

341

342

343

344

345

346

347

348

349

1955. Desloges (1994) attributed this decrease to reduced glacigenic input following retreat of glaciers from Little Ice Age maxima. This reduction in sediment delivery is to be expected because the area of the bed over which temperate glaciers slide is reduced (Hallet et al., 1996). Lower sedimentation rates are also expected as recently deglaciated forefields, which are important sources of fine-grained sediments, become stabilized. Desloges (1994) also attributed reductions in clastic sediment delivery, in some instances, to the formation of proglacial lakes within glacier forefields.

\subsection{Role of sediment sources and storage in persistence in the sediment-yield record}

Our results indicate that there is some persistence in the sediment yield record from Lillooet Lake.

Cumulative sediment yields after the most extreme events $\left(>Y_{100}\right)$ differ, but generally increase (Figure 6).

Sediment yield remains higher than the 40-year average up to one year after each event larger than $\mathrm{Y}_{25}$

(Figure 7). The persistence of high yields, however, probably depends on time-varying hydrological

conditions in the watershed. Coarse-grained sediment mobilized during an extreme event may persist in the fluvial system for several years in bars in river channels or easily eroded river banks. Thereafter, hydrological conditions within the watershed determine whether large amounts of sediment will continue to be mobilized. These conclusions are consistent with Lamoureux's (2002) observations that suspended sediment is rapidly transported and that suspended sediment yield after an extreme event is less sensitive than bedload yield to channel aggradation and degradation.

Reports and dates are available for major twentieth-century events (e.g. landslides and floods) that may have impacted sediment yield in the Lillooet River watershed. These data allow us to better interpret historic high-yield events. Persistence in the twentieth century is, however, difficult to evaluate (Figure 9), because high-yield events in the first half of the century happened, on average, once every 4.2 years. As discussed below, the high frequency of extreme-yield events during the first half of the twentieth century is 
A multi-century estimate of suspended sediment yield from Lillooet Lake

likely due to greater sediment availability resulting from glacier retreat from Little Ice Age maximum 351 positions.

\subsection{Interpretation of sediment-yield signal}

Jordan and Slaymaker (1991) provide a conceptual model for Holocene sediment transport in

354 glaciated mountainous watersheds based on their study of the Lillooet River watershed. They concluded

355 that Neoglacial deposits, debris flows, and landslides are the main sediment sources in the watershed. Here,

356 we consider the sediment-yield record from Lillooet Lake in terms of the sedimentary, geomorphic, and

357 anthropogenic processes operating within the Lillooet River watershed in the past. Each of these processes

358 can independently contribute to the sediment-yield signal, but they are interconnected and thus must be

359 considered together. For example, climate warming can cause glaciers to retreat, increasing stores of

360 sediment that are easily entrained and delivered to the fluvial system (Menounos et al., 2006; Menounos

361 and Clague, 2008), while leaving newly deglaciated slopes unstable and vulnerable to erosion landslides or

362 failure.

363 A consistent picture of late Holocene glacier activity in the southern Coast Mountains has emerged

364 from studies in this region (Larocque and Smith, 2003; Reyes and Clague, 2004; Menounos et al., 2004;

365 Allen and Smith, 2007; Koch et al., 2007, 2009; Clague et al., 2009, Mood and Smith, 2015). In Garibaldi

366 Provincial Park about 35-40 km southwest of Lillooet Lake, an early Little Ice Age advance in the twelfth

367 century was followed by glacier recession in the thirteenth century (Koch et al., 2007). Glaciers advanced

368 several times in the fourteenth and fifteenth centuries, and achieved their maximum Holocene extents

369 between AD 1690 and 1720 (Koch et al., 2007). Glaciers in Garibaldi Park and elsewhere in the southern

370 Coast Mountains did not commence substantial retreat until the beginning of the twentieth century (Figure

371 11). Similarly, farther north, in the Pacific Range of the Coast Mountains, glaciers advanced between 800 
A multi-century estimate of suspended sediment yield from Lillooet Lake

372 and 400 years ago (Mood and Smith, 2015). They reached their maximum positions in the late seventeenth

373 or early eighteenth century and began to retreat in the early twentieth century. A similar pattern of late

374 Holocene glacier advance and retreat has been documented in the Rocky Mountains and in the mountains

375 of Alaska and Washington State (Mood and Smith, 2015).

376 Sediment yield in the Lillooet River watershed, although high throughout the period AD 1629-1997, 377 increases from an average of $175 \pm 31 \mathrm{Mg} \mathrm{km}^{-2} \mathrm{a}^{-1}$ in the seventeenth century to $235 \pm 42 \mathrm{Mg} \mathrm{km}^{-2} \mathrm{a}^{-1}$ in

378 the twentieth century. This increase coincides with the episodic expansion of alpine glaciers to their Little 379 Ice Age maximum positions. The start of the twentieth century marks the beginning of the period with the 380 highest sediment yields - the average yield for the period AD 1900-1945 is $285 \pm 50 \mathrm{Mg} \mathrm{km}^{-2} \mathrm{a}^{-1}$. A

381 comparable increase in sediment yield in the early twentieth century has been documented at nearby Green 382 Lake (Menounos et al., 2006) and Cheakamus Lake (Menounos and Clague, 2008). These increases are 383 attributed to availability of sediments following rapid retreat of glaciers from their Little Ice Age maximum 384 positions.

385 Landslides, especially those originating from the Mount Meager massif, are also important sediment 386 sources. Two prehistoric landslides (Friele et al., 2008) in the headwaters of Meager Creek (Figure 1) have 387 calibrated radiocarbon age ranges of AD 1690-1790 and 1740-1860 (2- $\sigma$ ranges). The ages of these events 388 overlap with the age of two years of extreme sediment yields $\left(>Y_{100}\right)$, dated to AD 1776 and 1825 . The 389 year with the tenth largest sediment yield (AD 1713; $\mathrm{Y}_{50-100}$ category) is also within the age range of the 390 AD 1690-1790 landslide. The AD 1825 varve has no distinct sedimentological features other than being 391 thicker than average, but the AD 1713 and 1776 varves contain a thick sub-annual lamina. The AD 1776 392 varve also has a distinctive yellow colour in distal cores and a thick dark silt bed in proximal cores. This 393 event bed can be correlated with ease from core to core, and the distinctive yellow colour, possibly 
A multi-century estimate of suspended sediment yield from Lillooet Lake

394 indicative of fine volcanic sediment derived from Mount Meager, is faintly visible in the most distal core 395 (core E, Figure 12). The AD 1931 varve has a similar sedimentological signature (Figure 12); it coincides 396 with a debris flow with a volume of $3 \times 10^{6} \mathrm{~m}^{3}$ that descended Devastation Creek, near Mount Meager, that year (Friele et al., 2008). Suspended sediment yield after these prehistoric extreme events remains higher 399 Lake.

Friele et al. (2008) reported at least eight landslides with volumes larger than $10^{5} \mathrm{~m}^{3}$ in the Mount Meager Volcanic Complex during the twentieth century. Two of largest historic landslides, in AD 1931 (3 $402 \times 10^{6} \mathrm{~m}^{3}$; see above) and $1975\left(10^{7} \mathrm{~m}^{3}\right)$, coincide with peaks in the sediment yield record. Other historic 403 landslides in the Lillooet River watershed did not have an immediate effect on sedimentation in Lillooet 404 Lake, although a series of small landslides between AD 1986 and 1990 (Figure 13) may have preconditioned the watershed for the high sediment yields following a large flood in AD 1991.

There is a notable decrease in sediment yield after AD 1946 (Figure 13). We consider the possibility that the formation of Silt Lake or engineering works on Lillooet River are responsible for this decrease.

408 Proglacial Silt Lake began to form at the toe of Lillooet Glacier sometime between AD 1947 and 1962 409 (Schiefer and Gilbert, 2008). As the glacier continued to retreat, the lake rapidly grew in size and trapped 410 an increasing amount of suspended sediment $\left(10^{3} \mathrm{Mg} \mathrm{km}^{-2} \mathrm{a}^{-1}\right)$ that would otherwise have been transported

411 to Lillooet Lake. To evaluate the effect that Silt Lake has on sedimentation in Lillooet Lake, we considered 412 the extreme possibility that all upstream sediment bypasses Silt Lake. In this scenario, an additional 1.23\% 413 of suspended sediment reaches Lillooet Lake; this amount is within the error range of our sediment yield 414 estimate. It is thus improbable that changes in Silt Lake sediment storage significantly altered sediment 415 yields in the second half of the twentieth century. Major engineering works were undertaken in Lillooet 
A multi-century estimate of suspended sediment yield from Lillooet Lake

416 River valley in AD 1946 in response to a large flood in AD 1940. Sections of Lillooet River were

417 straightened and dyked and the level of Lillooet Lake was lowered $2.5 \mathrm{~m}$ between 1946 and 1952 (Jordan

418 and Slaymaker, 1991). The geomorphological and fluvial responses to these changes included down-

419 cutting and bank erosion by Lillooet River and an increase in the rate of advance of the Lillooet River delta

420 (Jordan and Slaymaker, 1991). Although the delta front advanced rapidly during the first five years after

421 the engineering works were completed, the amount of suspended sediment deposited farther south in the

422 lake does not appear to have increased (Figure 13).

423

\section{5. Conclusions}

425

426

427

428

429

430

431

432

433

434

435

436

437

We use an 825-year varve chronology, first examined by Heideman et al. (2015), to calculate and analyze sediment yields from the Lillooet River watershed. Cores nearest the Lillooet River delta span only part of the 825-year record and thus limit our sediment-yield estimates to the period AD 1629-1997. Our estimate of average suspended sediment yield for this 369 -year period is $213 \pm 38 \mathrm{Mg} \mathrm{km}^{-2} \mathrm{a}^{-1}$, comparable to the previous estimate of Desloges and Gilbert (1994). High sediment-yield years are unevenly distributed over the period - 13 of 34 extreme yield years are in the twentieth century, and 11 of the twentieth-century extreme yield years were before AD 1946.

High sediment yields in the seventeenth, eighteenth, and nineteenth centuries coincide with the time

of maximum Little Ice Age glacier cover in the watershed. We attribute increased sedimentation in Lillooet Lake in the early part of the twentieth century to enhanced mobilization and delivery of glacigenic sediments to the lake following glacier retreat. Lower average sediment yields in the second half of twentieth century appear to result principally from stabilization of recently deglaciated terrain by vegetation and river training. 
A multi-century estimate of suspended sediment yield from Lillooet Lake

Peaks in sediment yield in the second half of the twentieth century have complex relations with

439 Lillooet River discharge and major landslides at Mount Meager (Figure 13). For example, a large historic

440 landslide in 1975, which occurred shortly before a high flow event on Lillooet River, produced a varve that

441 is only in the $\mathrm{Y}_{10-25}$ category. In contrast, the thick 1991 varve $\left(\mathrm{Y}_{25-50}\right)$ is attributed to a series of landslides

442 in years leading up 1991, in combination with the one of the largest Lillooet River floods on record.

443 We interpret the sediment-yield record in Lillooet Lake in terms of the complex connectivity among a

444 variety of sediment sources and climatic, geomorphic, and anthropogenic processes, among which glacier

445 activity, landslides, and river engineering play a role. The variety of processes that shape the mountainous

446 Lillooet River watershed makes it difficult to disentangle causative events; as a result, interpretations of

447 specific annual yields remain inconclusive. In addition, our estimates of sediment delivery to Lillooet Lake

448 do not include bedload, thus there are large uncertainties in total clastic yield to the lake. Nevertheless,

449 variations in the suspended sediment component of the total clastic yield are consistent with what is known

450 about the regional glacial and landslide history of the watershed.

452 7. Acknowledgements

453 This research was made possible with grants to John Clague and Brian Menounos from the Canada

454 Research Chairs Program, Canada Foundation for Innovation (CFI), and Natural Sciences and Engineering

455 Research Council of Canada (NSERC). We thank Melanie Grubb and Tom Lakeman for their assistance in

456 the field and in the laboratory. Joseph Desloges provided constructive comments that helped us

457 significantly improve the paper.

458

459 References 
A multi-century estimate of suspended sediment yield from Lillooet Lake

460

461

462

463

464

465

466

467

468

469

470

471

472

473

474

475

476

477

478

479

480

481

482

Allen, S.M. and Smith, D.J. 2007. Late Holocene glacial activity of Bridge Glacier, British Columbia Coast Mountains. Canadian Journal of Earth Sciences, 44, 1753-1773.

Church, M. and Slaymaker, O. 1989. Disequilibrium of Holocene sediment yield in glaciated British Columbia. Nature, 337(6206), 452-454.

Clague, J.J., Evans, S.G., Rampton, V.N. and Woodsworth, G.J. 1995. Improved age estimates for the White River and Bridge River tephras, western Canada. Canadian Journal of Earth Sciences, 32, 11721179.

Clague, J.J., Menounos, B., Osborn, G., Luckman, B.H. and Koch, J. 2009. Nomenclature and resolution in Holocene glacial chronologies. Quaternary Science Reviews, 28, 2231-2238.

Desloges, J.R. 1994. Varve deposition and the sediment yield record at three small lakes of the southern Canadian Cordillera. Arctic and Alpine Research, 26, 130-140.

Desloges, J.R. and Gilbert, R. 1991. Sedimentary record of Harrison Lake: Implications for deglaciation in southwestern British Columbia. Canadian Journal of Earth Sciences, 28, 800-815.

Desloges, J.R. and Gilbert, R. 1994. Sediment source and hydroclimatic inferences from glacial lake sediments; the postglacial sedimentary record of Lillooet Lake, British Columbia. Journal of Hydrology, 159(1-4), 375-393.

Desloges, J.R. and Gilbert, R. 1995. The sedimentary record of Moose Lake: Implications for glacier activity in the Mount Robson area, British Columbia. Canadian Journal of Earth Sciences, 32, 65-78.

Desloges, J.R. and Gilbert, R. 1998. Sedimentation in Chilko Lake: A record of the geomorphic environment of the eastern Coast Mountains of British Columbia, Canada. Geomorphology, 25, 75-91.

Environment Canada. 2010. Water Survey of Canada - Archived hydrometric data. Available from http://www.wsc.ec.gc.ca/applications/H2O/ [Accessed 27 September 2010]. 
A multi-century estimate of suspended sediment yield from Lillooet Lake

483 484 485 486 487 488 489 490 491 492 493 494 495 496 497 498 499 500 501 502 503 504

Environment Canada. 2011. National Climate Data and Information Archive. Available from http://www.climate.weatheroffice.gc.ca/climateData/ [Accessed 19 January 19 2012].

Evans, S.G. 1987. A rock avalanche from the peak of Mount Meager, British Columbia. Geological Survey of Canada Paper, 87-1A, 929-934.

Friele, P.A. and Clague, J.J. 2004. Large Holocene landslides from Pylon Peak, southwestern British Columbia. Canadian Journal of Earth Sciences, 41, 165-182.

Friele, P.A., Jakob, M. and Clague, J.J. 2008. Hazard and risk from large landslides from Mount Meager volcano, British Columbia, Canada. Georisk, 2, 48-64.

Gilbert, R. 1972. Observations on sedimentation at Lillooet delta, British Columbia. In H.O. Slaymaker and H.J. McPherson (Eds.), Mountain geomorphology: Geomorphological processes in the Canadian Cordillera (B.C. Geographical Series, 14, 187-194). Vancouver, BC: Tantalus Research Limited.

Gilbert, R. 1973. Observations of lacustrine sedimentation at Lillooet Lake, British Columbia. PhD dissertation, University of British Columbia, Vancouver, BC.

Gilbert, R. 1975. Sedimentation in Lillooet Lake, British Columbia. Canadian Journal of Earth Sciences, $12,1697-1711$.

Gilbert, R., Desloges, J.R. and Clague, J.J. 1997. The glaciolacustrine sedimentary environment of Bowser Lake in the northern Coast Mountains of British Columbia, Canada. Journal of Paleolimnology, 17, $331-346$.

Gimp2 2012. GNU image manipulation program. Available from http://www.gimp.org/ [Accessed 3 February 2012].

Guthrie, R., Friele, P., Allstadt, K.B., Roberts, N., Evans, S.G., Delaney, K., Roche, D., Clague, J.J. and Jakob, M. 2012. The 6 August 2010 Mount Meager rock slide-debris flow, Coast Mountains, British 
A multi-century estimate of suspended sediment yield from Lillooet Lake

Columbia; characteristics, dynamics, and implications for hazard and risk assessment. Natural Hazards and Earth System Sciences, 12, 1-18.

Hallet, B., Hunter, L., and Bogen, J. 1996. Rates of erosion and sediment evacuation by glaciers: A review of field data and their implications. Global and Planetary Change, 12, 213-235.

Heideman, M., Menounos, B. and Clague, J.J. 2015. An 825-year long varve record from Lillooet Lake, British Columbia, and its potential as a flood proxy. Quaternary Science Reviews, 126, 158-174.

Hodder, K.R. 2009. Flocculation: a key process in the sediment flux of a large, glacier-fed lake. Earth Surface Processes and Landforms, 34, 1151-1163.

Hosking, J.R.M. and Wallis, J.R. 1986. Paleoflood hydrology and flood frequency analysis. Water Resources Research, 22, 543-550.

Jenkinson, A.F. 1955. The frequency distribution of the annual maximum (or minimum) of meteorological elements. Quarterly Journal of the Royal Meteorological Society, 81, 158-171.

Jordan, P. and Slaymaker, O. 1991. Holocene sediment production in Lillooet River basin, British Columbia; a sediment budget approach. Géographie physique et Quaternaire, 45, 45-57.

Koch, J., Clague, J.J. and Osborn, G.D. 2007. Glacier fluctuations during the past millennium in Garibaldi Provincial Park, southern Coast Mountains, British Columbia. Canadian Journal of Earth Sciences, 44, $1215-1233$.

Koch, J., Menounos, B. and Clague, J.J. 2009. Glacier change in Garibaldi Park, southern Coast Mountains, British Columbia, since the Little Ice Age. Global and Planetary Change, 66, 161-178.

Koi, T., Hotta, N., Ishigaki, I., Matuzaki, N., Uchiyama, Y. and Suzuki, M. 2008. Prolonged impact of earthquake-induced landslides on sediment yield in a mountain watershed: The Tanzawa region, Japan. Geomorphology, 101, 692-702. 
A multi-century estimate of suspended sediment yield from Lillooet Lake

527 Lamoureux, S. 2000. Five centuries of interannual sediment yield and rainfall-induced erosion in the 528 Canadian high arctic recorded in lacustrine varves. Water Resources Research, 36, 309-318.

529 Lamoureux, S. 2002. Temporal patterns of suspended sediment yield following moderate to extreme 530 hydrological events recorded in varved lacustrine sediments. Earth Surface Processes and Landforms, $531 \quad 27,1107-1124$.

532 Larocque, S.J. and Smith, D.J. 2003. Little Ice Age glacial activity in the Mt. Waddington area, British 533 Columbia Coast Mountains, Canada. Canadian Journal of Earth Sciences, 40, 1413-1436.

534 Leonard, E.M. 1997. The relationship between glacial activity and sediment production: Evidence from a 535 4450-year varve record of neoglacial sedimentation in Hector Lake, Alberta, Canada. Journal of 536 Paleolimnology, 17, 319-330.

537 Loso, M.G., Anderson, R.S. and Anderson, S.P. 2004. Post-Little Ice Age record of coarse and fine clastic 538 sedimentation in an Alaskan proglacial lake. Geology, 32, 1065-1068.

Major, J.J., Pierson, T.C., Dinehart, R. L. and Costa, J.E. 2000. Sediment yield following severe volcanic disturbance - A two-decade perspective from Mount St. Helens. Geology, 28, 819-822.

Menounos, B. and Clague, J.J. 2008. Reconstructing hydro-climatic events and glacier fluctuations over the past millennium from annually laminated sediments of Cheakamus Lake, southern Coast Mountains,

544 Menounos, B., Clague, J.J., Gilbert, R. and Slaymaker, O. 2005. Environmental reconstruction from a varve network in the southern Coast Mountains, British Columbia, Canada. The Holocene, 15, 11631171.

547 Menounos, B., Koch, J. Osborn, G., Clague, J.J. and Mazzucchi, D. 2004. Early Holocene glacier advance, southern Coast Mountains, British Columbia, Canada. Quaternary Science Reviews, 23, 1543-1550. 
A multi-century estimate of suspended sediment yield from Lillooet Lake

549

550

551

552

553

554

555

556

557

558

559

560

561

562

563

564

565

566

567

568

569

570

Menounos, B., Schiefer, E. and Slaymaker, O. 2006. Nested temporal suspended sediment yields, Green Lake basin, British Columbia, Canada. Geomorphology, 79, 114-129.

Mood, B.J. and Smith, D.J. 2015. Holocene glacier activity in the British Columbia Coast Mountains, Canada. Quaternary Science Reviews, 128, 14-36.

Mokievsky-Zubok, O. 1977. Glacier-caused slide near Pylon Peak, British Columbia. Canadian Journal of Earth Sciences, 15, 1039-1052.

O'Hara, S.L., Street-Perrott, F.A. and Burt, T.P. 1993. Accelerated soil erosion around a Mexican highland lake caused by prehispanic agriculture. Nature, 362, 48-51.

Onstad, C.A. 1984. Sediment yield modelling. In R.F. Hadley and D.E. Walling (Eds.), Erosion and sediment yield: Some methods of measurement and modelling (pp. 71-89). Norwich, England: Geo Books.

Pacific Climate Impacts Consortium 2016. High-Resolution PRISM Climatology. Available from http://tools.pacificclimate.org/dataportal/bc_prism/map/ [cited 1 June 2016].

Panofsky, H.A. and Brier, G.W. 1958. Some applications of statistics to meteorology. University Park, PA: Pennsylvania State University.

Read, P.B. 1979. Geology Meager Creek geothermal area, British Columbia. Geological Survey of Canada Open File 603.

Read, P.B. 1990. Mount Meager Complex Garibaldi Belt, southwestern British Columbia. Geoscience Canada, 17, 167-170.

Reyes, A.V. and Clague, J.J. 2004. Stratigraphic evidence for multiple Holocene advances of Lillooet Glacier, southern Coast Mountains, British Columbia. Canadian Journal of Earth Sciences, 41, 903918. 
A multi-century estimate of suspended sediment yield from Lillooet Lake

571 Roche, A.D., Ellis, E., Guthrie, R.H., Roberts, N.J. and Friele, P. 2011. Once more into the breach: A 572 forensic analysis of the August 2010 landslide dam outburst flood at Meager Creek, BC. Proceedings, 573 Geohazards 5 Conference, Kelowna, BC.

574 Schiefer, E. 2006. Contemporary sedimentation rates and depositional structures in a montane lake basin, 575 southern Coast Mountains, British Columbia, Canada. Earth Surface Processes and Landforms, 31,

Schiefer, E. and Gilbert, R. 2008. Proglacial sediment trapping in recently formed Silt Lake, upper Lillooet $1311-1324$. valley, Coast Mountains, British Columbia. Earth Surface Processes and Landforms, 33, 1542-1556.

Schiefer, E. and Klinkenberg, B. 2004. The distribution and morphometry of lakes and reservoirs in British Columbia: A provincial inventory. The Canadian Geographer, 48, 345-355.

Schiefer, E., Slaymaker, O. and Klinkenberg, B. 2001. Physiographically controlled allometry of specific sediment yield in the Canadian Cordillera: A lake sediment-based approach. Geografiska Annaler, 83,

584 Schiefer, E., Hassan, M., Menounos, B., Pelpolad, C. and Slaymaker, O. 2010. Interdecadal patterns of total sediment yield from a montane catchment, southern Coast Mountains, British Columbia, Canada. Geomorphology, 118, 207-212.

Slaymaker, O. 1972. Sediment yield and sediment control in the Canadian Cordillera. In H.O. Slaymaker and H.J. McPherson (Eds.), Mountain geomorphology: Geomorphological processes in the Canadian Cordillera (B.C. Geographical Series No.14, pp. 235-245). Vancouver, BC: Tantalus Research

591 Taylor, J.R. 1982. An introduction to error analysis. The study of uncertainties in physical measurement 592 (1st ed.). Mill Valley, CA: University Science Books. 
A multi-century estimate of suspended sediment yield from Lillooet Lake

593 Wohl, E., Magilligan, F.J., Rathbum, S.L. 2017. Introduction to the special issue: Connectivity in 594 Geomorphology. Geomorphology, 277, 1-5.

595 Zolitschka, B. 1998. A 14,000 year sediment yield record from western Germany based on annually 596 laminated lake sediments. Geomorphology, 22, 1-17.

597 
A multi-century estimate of suspended sediment yield from Lillooet Lake

\section{Tables}

599

600 Table 1. Sediment yield estimates (in tonnes $\mathrm{km}^{-2} \mathrm{a}^{-1}$ ) for the entire period of record 601 (AD 1179-1629) and 1629-1997.

\begin{tabular}{lccc}
\hline Period & AD 1179-2004 & AD 1179-1628 & AD 1629-1692 \\
\hline Mean ( \pm 1 standard deviation) & $158.9 \pm 28$ & $111.4 \pm 20$ & $213.1 \pm 3803$ \\
Minimum & 35.5 & 35.5 & 74.3 \\
Maximum & 1184.1 & 1184.1 & 672.3604 \\
\hline
\end{tabular}

605

606

607

608 Table 2. Number of years with sediment yields greater than specified estimated return periods.

\begin{tabular}{lccccc}
\hline & \multicolumn{5}{c}{ Return period } \\
\cline { 2 - 5 } Century (AD) & $>\mathrm{Y}_{100}$ & $\mathrm{Y}_{50-100}$ & $\mathrm{Y}_{25-50}$ & $\mathrm{Y}_{10-25}$ & Total \\
\hline $1900-1997$ & 3 & 1 & 3 & 6 & 13 \\
$1800-1899$ & 1 & 1 & - & 5 & 7 \\
$1700-1799$ & 1 & 1 & 1 & 6 & 9 \\
$1629-1699$ & - & 1 & 1 & 3 & 5 \\
Total & 5 & 4 & 5 & 20 & 34 \\
\hline
\end{tabular}

609 Note: $>Y_{100}=$ sediment yield $(\mathrm{Y})$ with an estimated return period greater than once every 100 610 years; $Y_{50-100}=$ sediment yields with estimated return periods between 50 and 100 years; etc. 
A multi-century estimate of suspended sediment yield from Lillooet Lake

614 Table 3. Comparison of sediment yield estimates derived from this (AD 1629-2004) and other published 615 studies.

\begin{tabular}{lllll}
\hline Study & This study & Slaymaker (1972) & Gilbert (1973) & $\begin{array}{l}\text { Desloges and } \\
\text { Gilbert (1994) }\end{array}$ \\
\hline $\begin{array}{l}\text { Sediment yield (Mg } \\
\left.\mathrm{km}^{-2} \mathrm{a}^{-}\right)^{\mathrm{a}}\end{array}$ & 213 & 386 & $334^{\mathrm{b}}$ & $188-218$ \\
$\begin{array}{l}\text { Component of total } \\
\text { sediment yield }\end{array}$ & $\begin{array}{l}\text { Average annual } \\
\text { long-term } \\
\text { suspended } \\
\text { sediment yield }\end{array}$ & Suspended load & $\begin{array}{l}\text { Annual suspended } \\
\text { load }\end{array}$ & $\begin{array}{l}\text { Annual total basin } \\
\text { yield, fine fraction }\end{array}$ \\
& Varves & & \\
$\begin{array}{l}\text { Estimate derived } \\
\text { from }\end{array}$ & $?$ & Varves and pro-delta & Varves \\
$\begin{array}{l}\text { Original reported } \\
\text { yield }\end{array}$ & & $1450 \times 10^{3}$ & sediments & \\
Period & tonnes a & $1.1 \times 10^{6} \mathrm{~m}^{3} \mathrm{a}^{-1}$ & $6.2-7.2 \times 10^{5} \mathrm{~m}^{3} \mathrm{a}^{-}$ \\
\hline
\end{tabular}

$616{ }^{a}$ Estimates recalculated to $\mathrm{Mg} \mathrm{km}^{-2} \mathrm{a}^{-1}$ to compare with the results of this study.

$617{ }^{\mathrm{b}}$ Gilbert (1973) estimated the volume of sediment accumulating on the pro-delta to be $5.3 \times 10^{7} \mathrm{~m}^{3}$ and in 618 the rest of the lake $6.3 \times 10^{6} \mathrm{~m}^{3}$ for the period 1913-1969 (total $1.1 \times 10^{6} \mathrm{~m}^{3} \mathrm{a}^{-1}$, equivalent to $334 \mathrm{Mg} \mathrm{km}^{-2}$ $\left.619 \mathrm{a}^{-1}\right)$.

$620{ }^{c}$ Total basin yield of the fine fraction $(<63 \mu \mathrm{m})$. Desloges and Gilbert (1994) estimated the total basin 621 yield (fine and coarse fraction) to be $15.5-16.5 \times 10^{5} \mathrm{~m}^{3} \mathrm{a}^{-1}$, equivalent to $472-501 \mathrm{Mg} \mathrm{km}^{-2} \mathrm{a}^{-1}$. 
A multi-century estimate of suspended sediment yield from Lillooet Lake

623

624

625

626

627

628

629

630

631

632

63325 years).

634

635

636

637 Figure 6. Cumulative departure from AD 1629-1997 mean sediment yield for each group of recurrence

638 interval group (6a: $\left.>\mathrm{Y}_{100} ; 6 \mathrm{~b}: \mathrm{Y}_{50-100} ; 6 \mathrm{c}: \mathrm{Y}_{25-50}\right)$

639

640 Figure 7. Cumulative departure from AD 1629-1997 mean sediment yield for events with a recurrence

641 interval between 10 and 25 years $\left(\mathrm{Y}_{10-25} ; 7 \mathrm{a}=\right.$ seventeenth century; $7 \mathrm{~b}=$ eighteenth century; $7 \mathrm{c}=$

642 nineteenth century; $7 \mathrm{~d}=$ twentieth century; black = average cumulative departure of all $\mathrm{Q}_{10-25}$ events).

644 Figure 8. Deviations from the mean over the period extending from 10 years before to 30 years after each 
A multi-century estimate of suspended sediment yield from Lillooet Lake

645 high-yield year for groups with different recurrence intervals over the period AD 1629-1997. Red column 646 is event year ' 0 '.

648 Figure 9. Deviations from the mean over the period extending from 10 years before to 30 years after each 649 high-yield year for groups with different recurrence intervals over the twentieth century. Red column is 650 event year ' 0 '.

651

652 Figure 10. Comparison of suspended sediment yield for the Lillooet River watershed (this study; red circle 653 with error bars) and specific sediment yield (i.e. "the quantity of sediment passing a monitored river cross654 section per unit area drained upstream of that section"; Church and Slaymaker, 1989, p. 452) in British

655 Columbia. Closed symbols are data from natural landscapes; open symbols are data from landscapes 656 influenced by natural or human disturbances. Measurements for Lillooet Lake are derived from a 57-year 657 record of lake sedimentation reported by Gilbert (1973). Modified from Church and Slaymaker (1989).

658

659 Figure 11. Summary diagram comparing sediment yield in the Lillooet River watershed (bottom), dated 660 landslides at Mount Meager (Friele et al., 2008), and glacier fluctuations in western Canada (top; modified 661 from Clague et al., 2009) and Garibaldi Provincial Park (middle; modified from Koch et al., 2007).

662 Horizontal bars show uncertainties in the ages of prehistoric landslides.

663

664 Figure 12. (a) AD 1931 and (b) 1776 varves from Lillooet Lake cores C, 2, and E (left to right; proximal to 665 distal core locations). The vertical black bar at lower left of each photograph is $1 \mathrm{~cm}$. 
A multi-century estimate of suspended sediment yield from Lillooet Lake

667 Figure 13. Sediment yield and maximum daily discharge of Lillooet River during the twentieth century. 


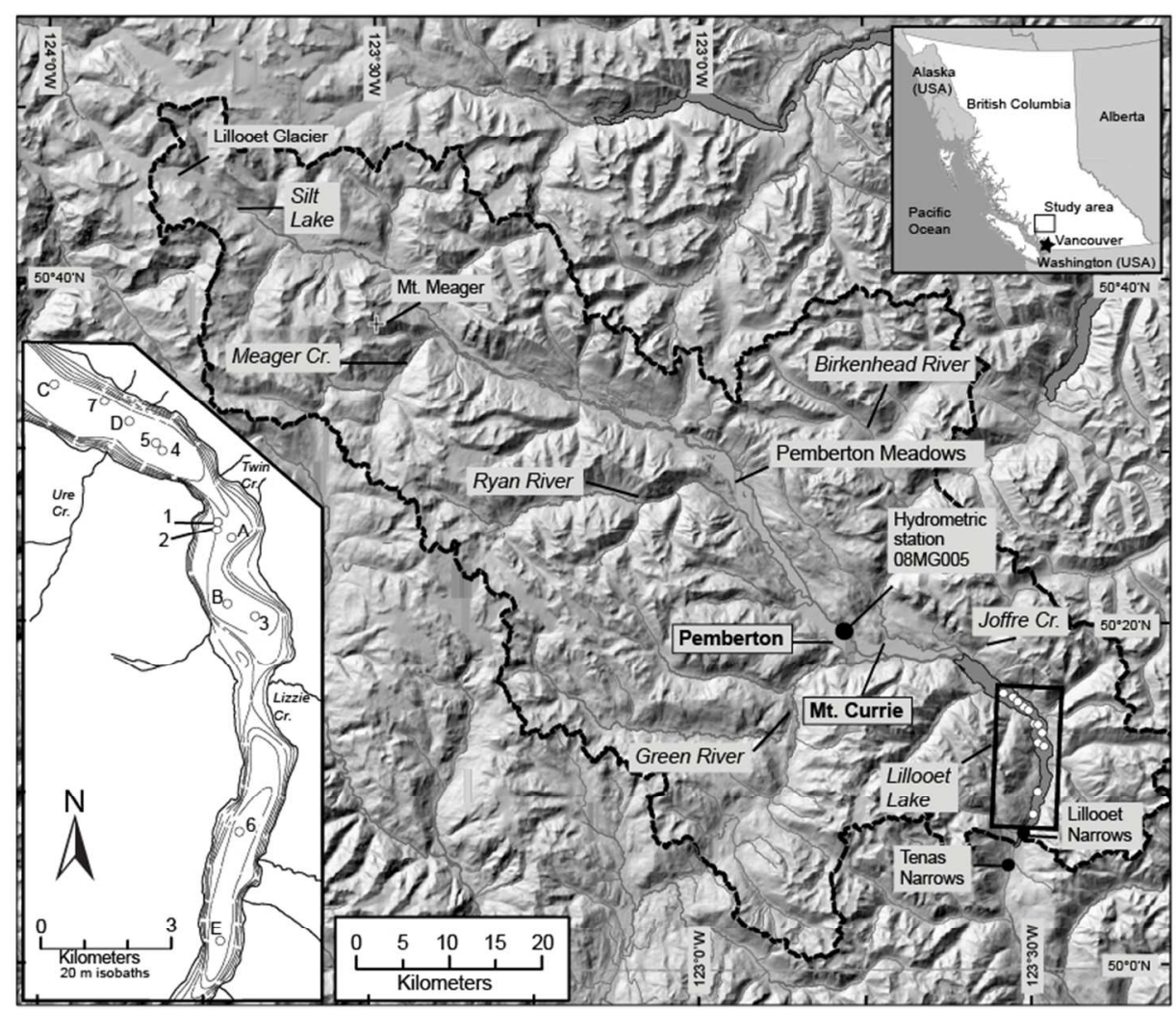

Article Map 


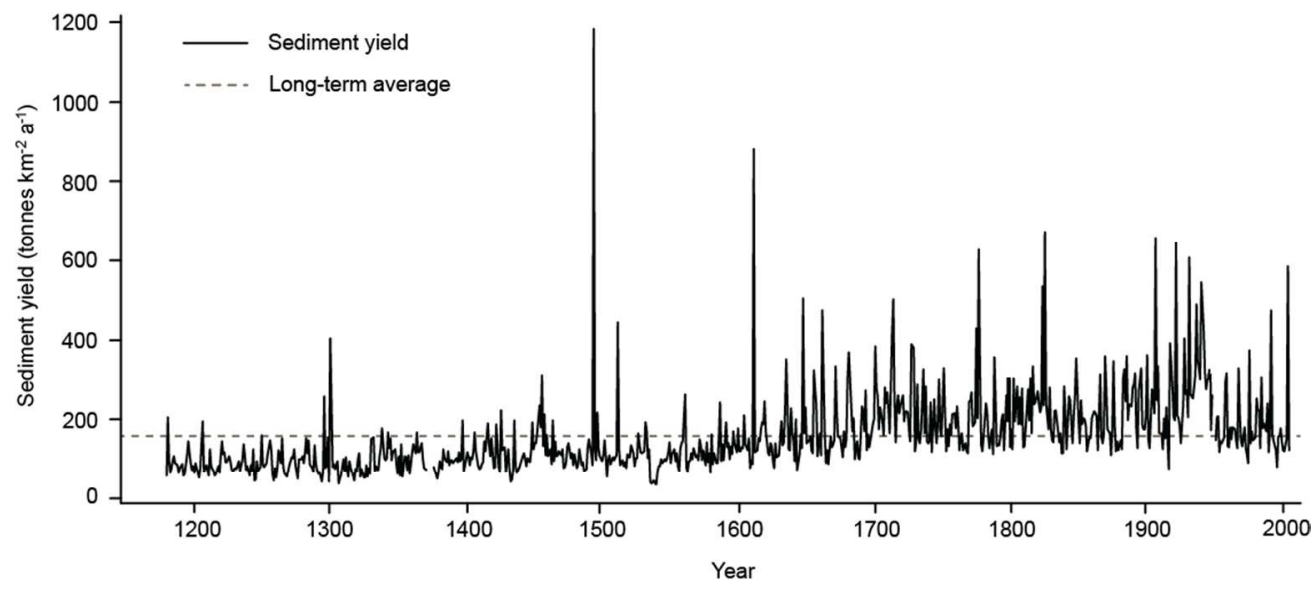

Long-term sediment yield 


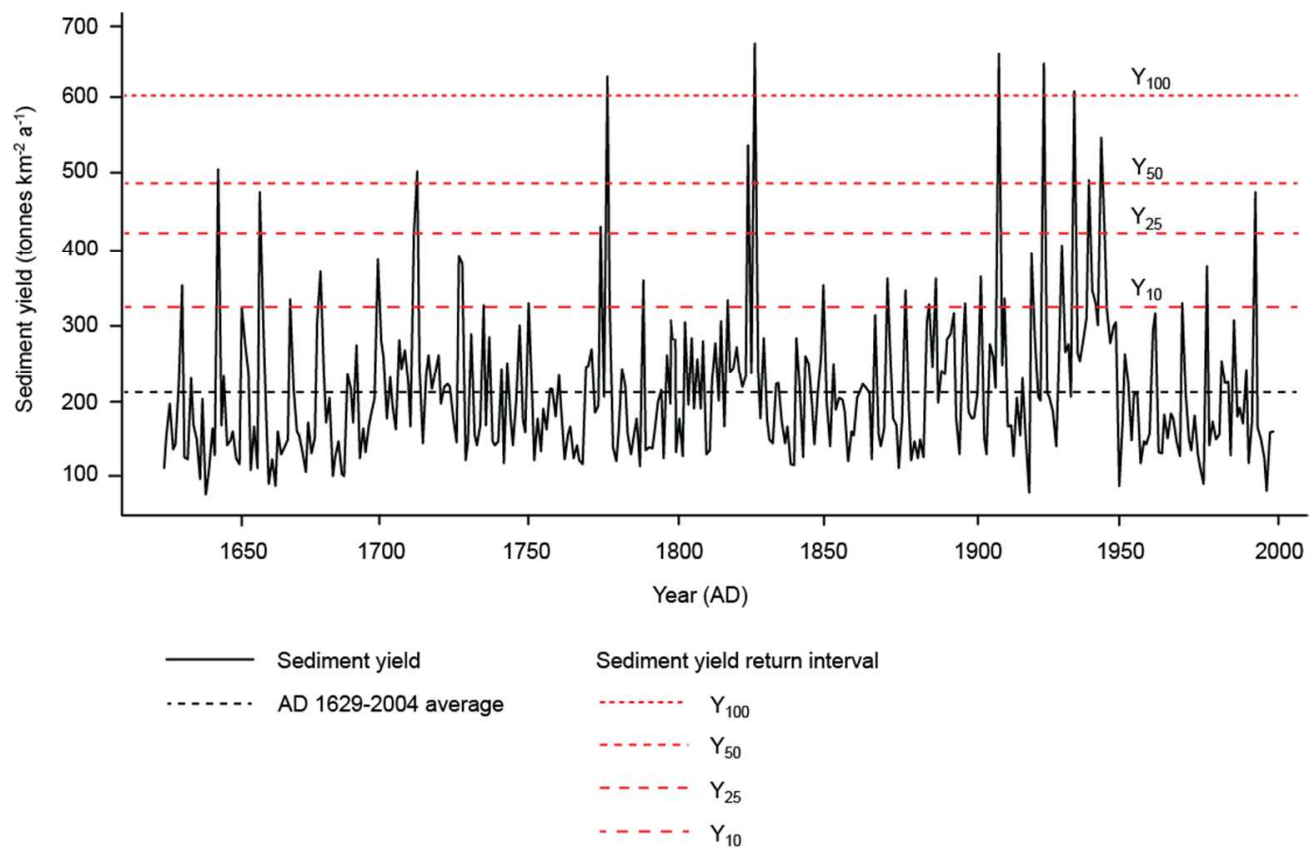

Sediment yield post AD 1629 


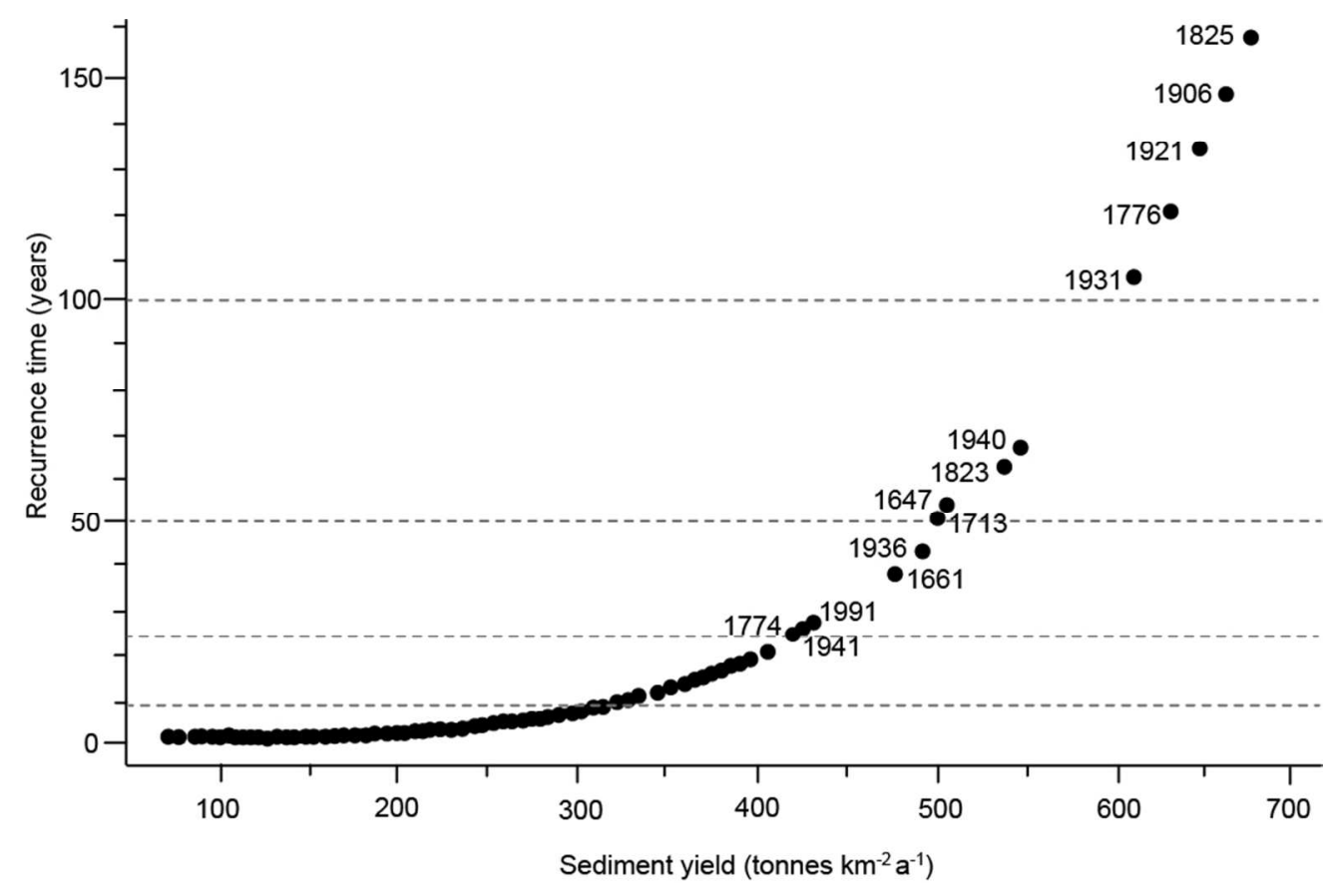

Recurrence intervals 


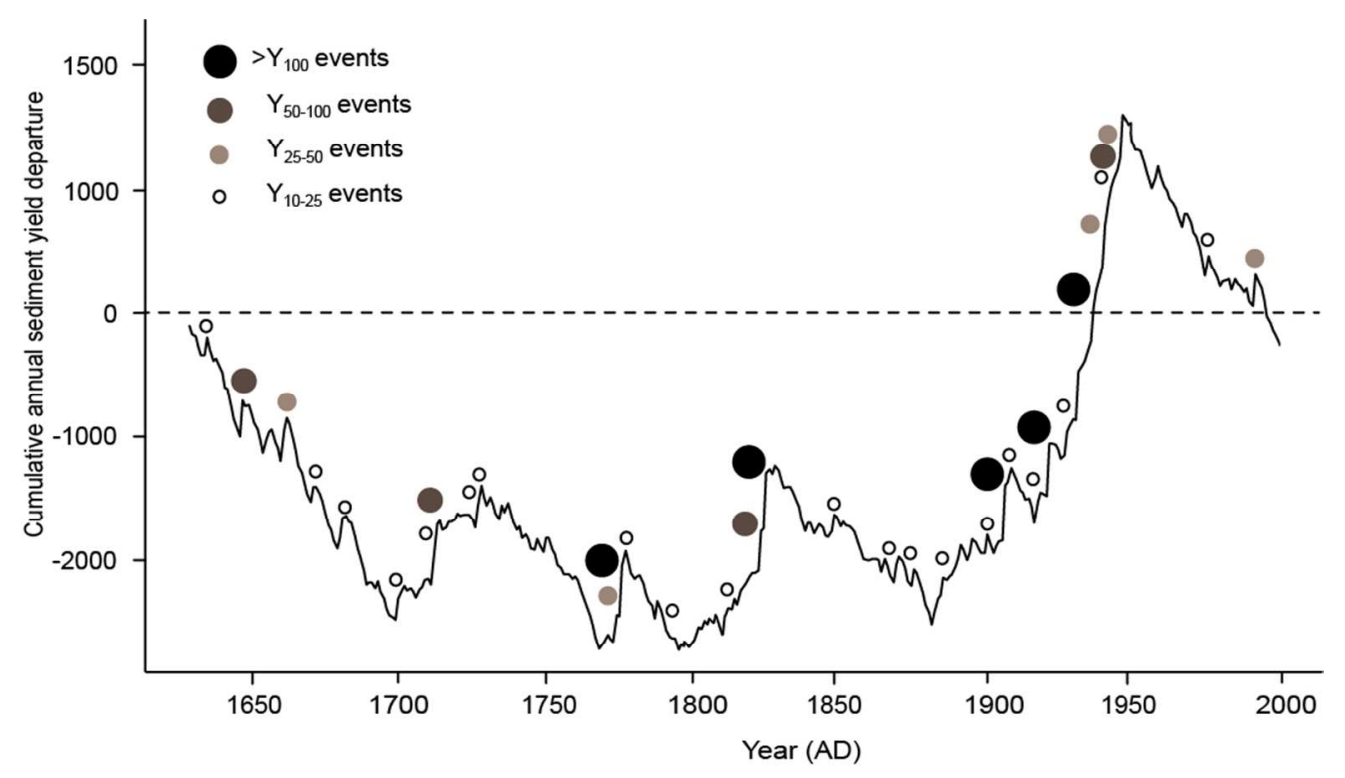

Cumulative departure 1629-19987 

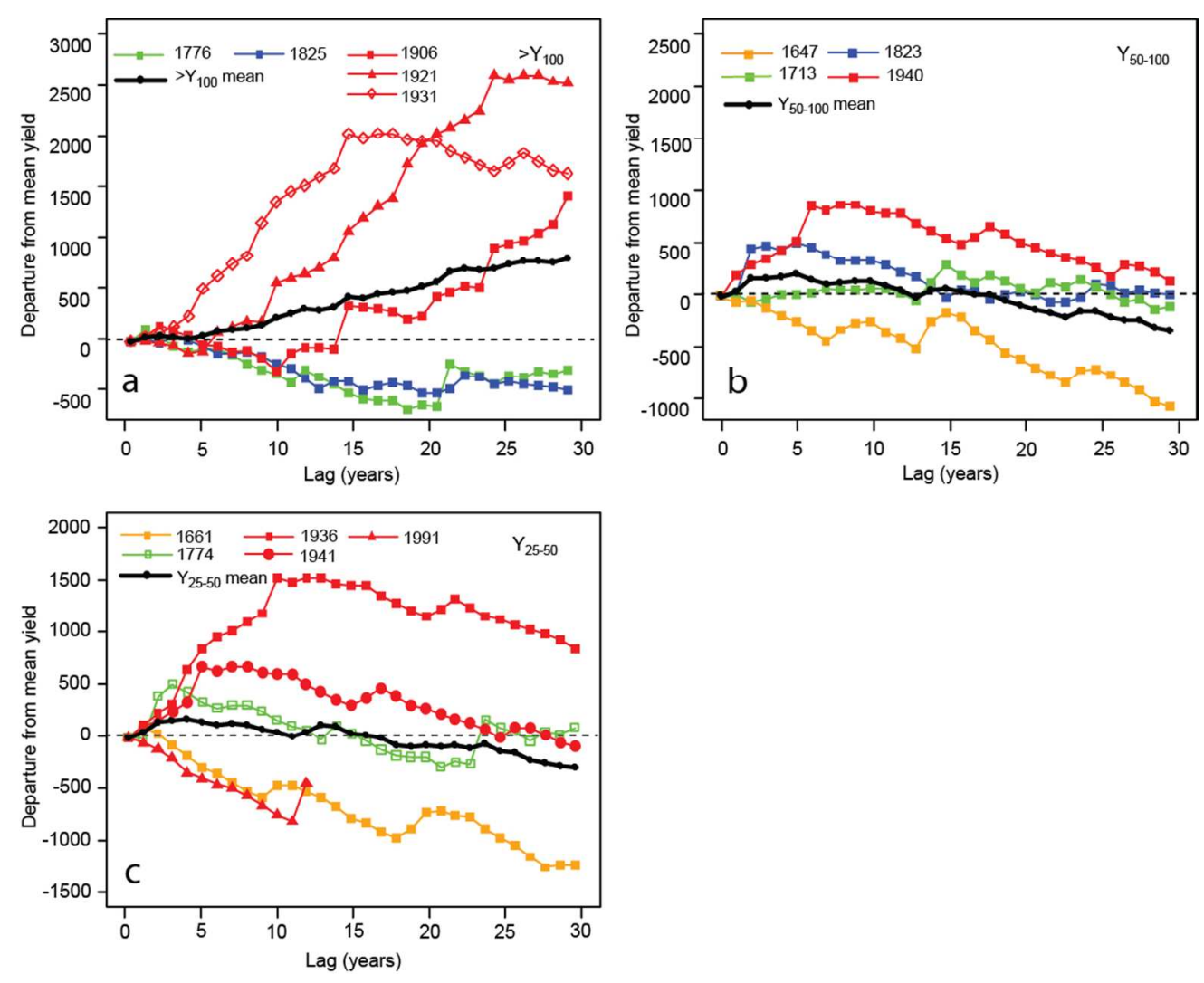

Cumulative departures 

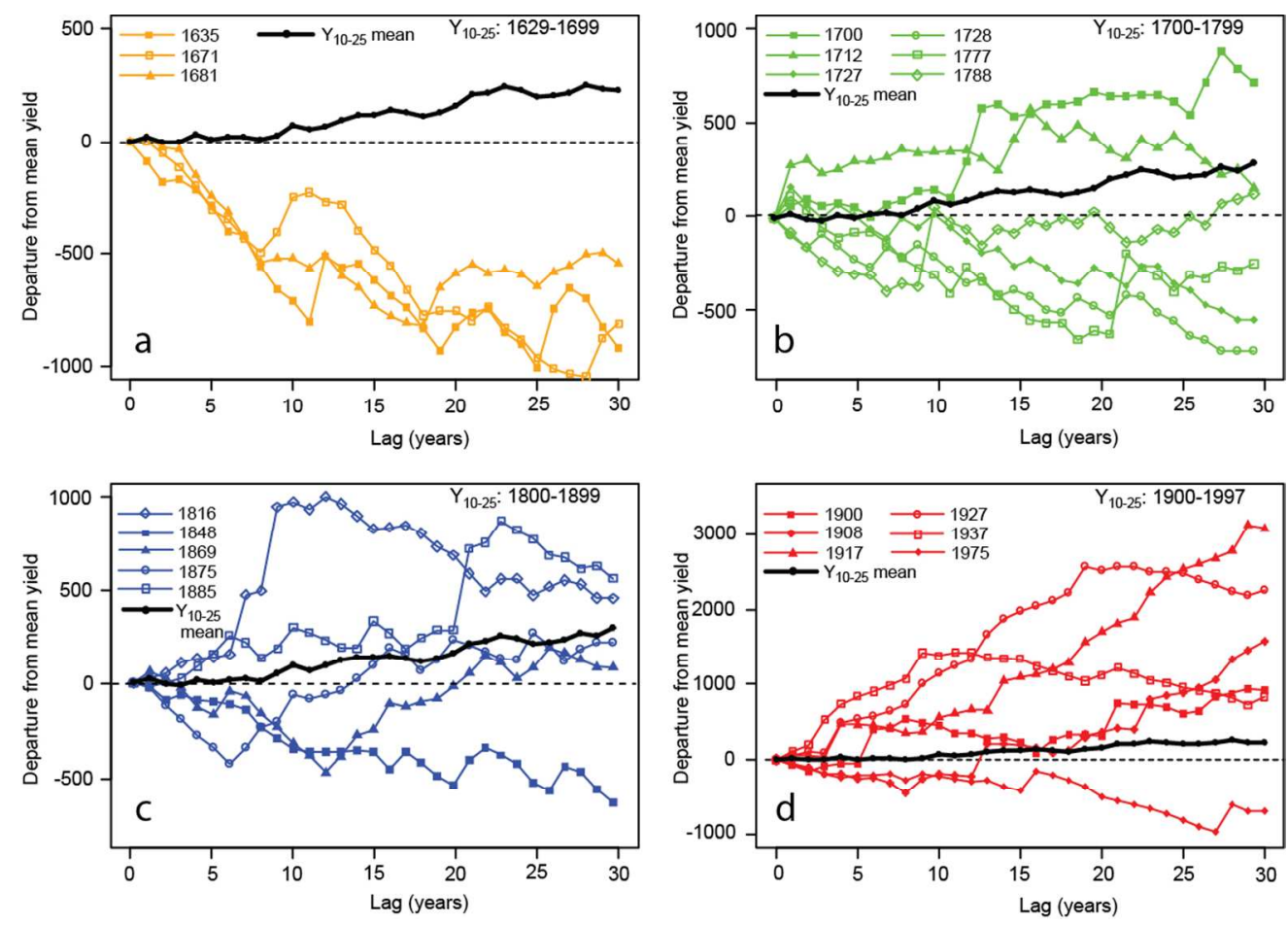

Cumulative departures Q10 

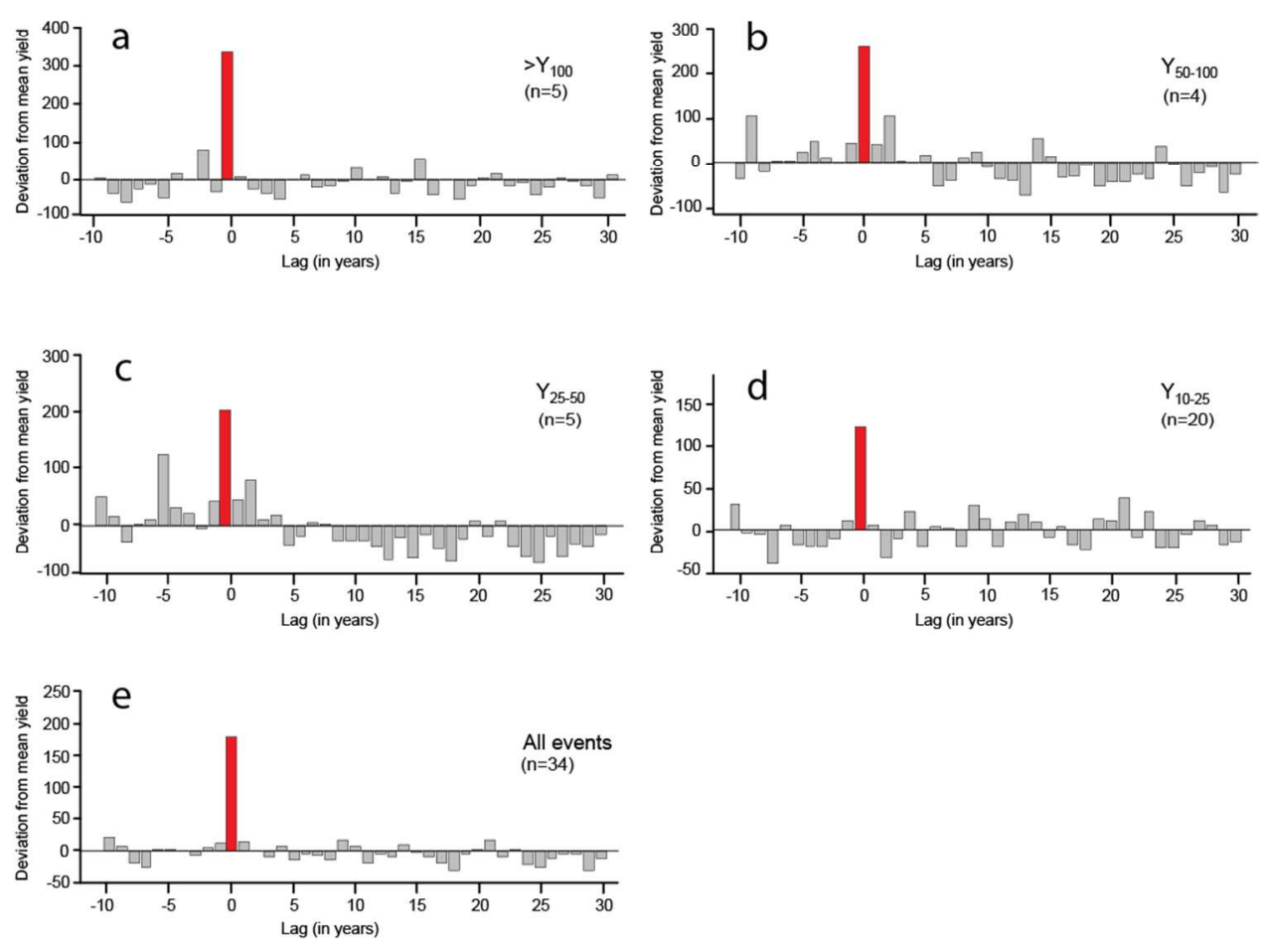

Persistence post 1629 

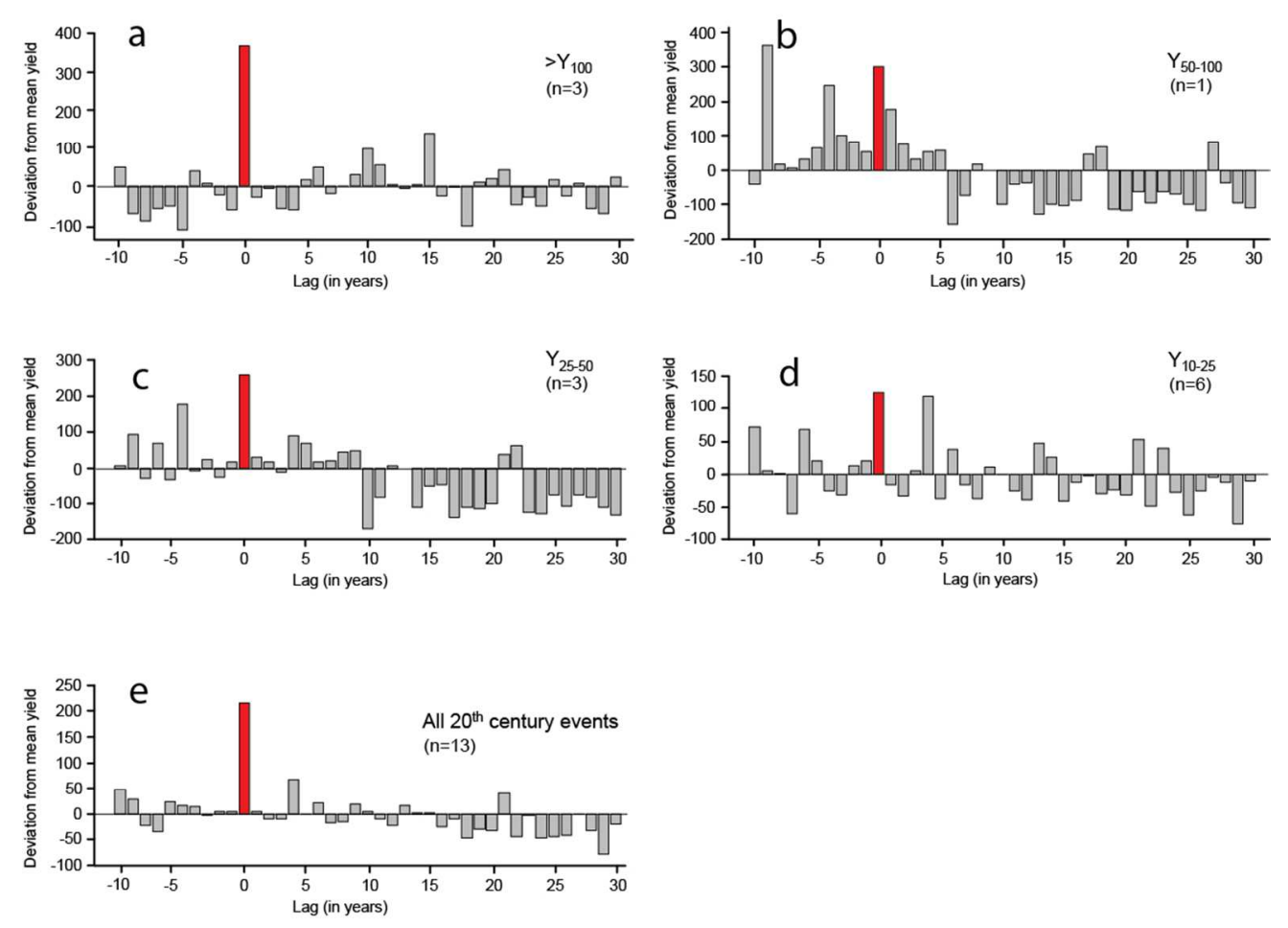

Persistence 20th century 


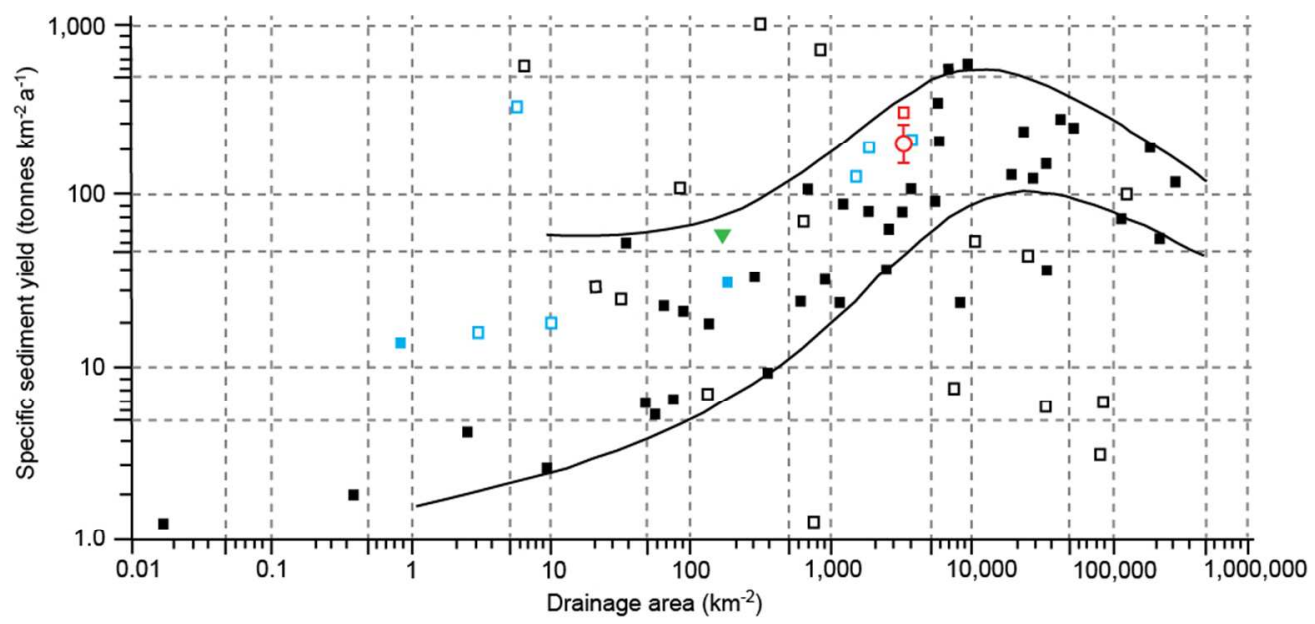

Data Church et al., 1989:

- Undistributed catchments

I Lillooet Lake (current study)

口 Disturbed catchments

$\nabla$ Green Lake (Menounos et al., 2006)

- Coast Mountain (undisturbed)

$\square$ Coast Mountain (disturbed)

$\square$ Lillooet Lake

sediment yield vs. drainage basin 


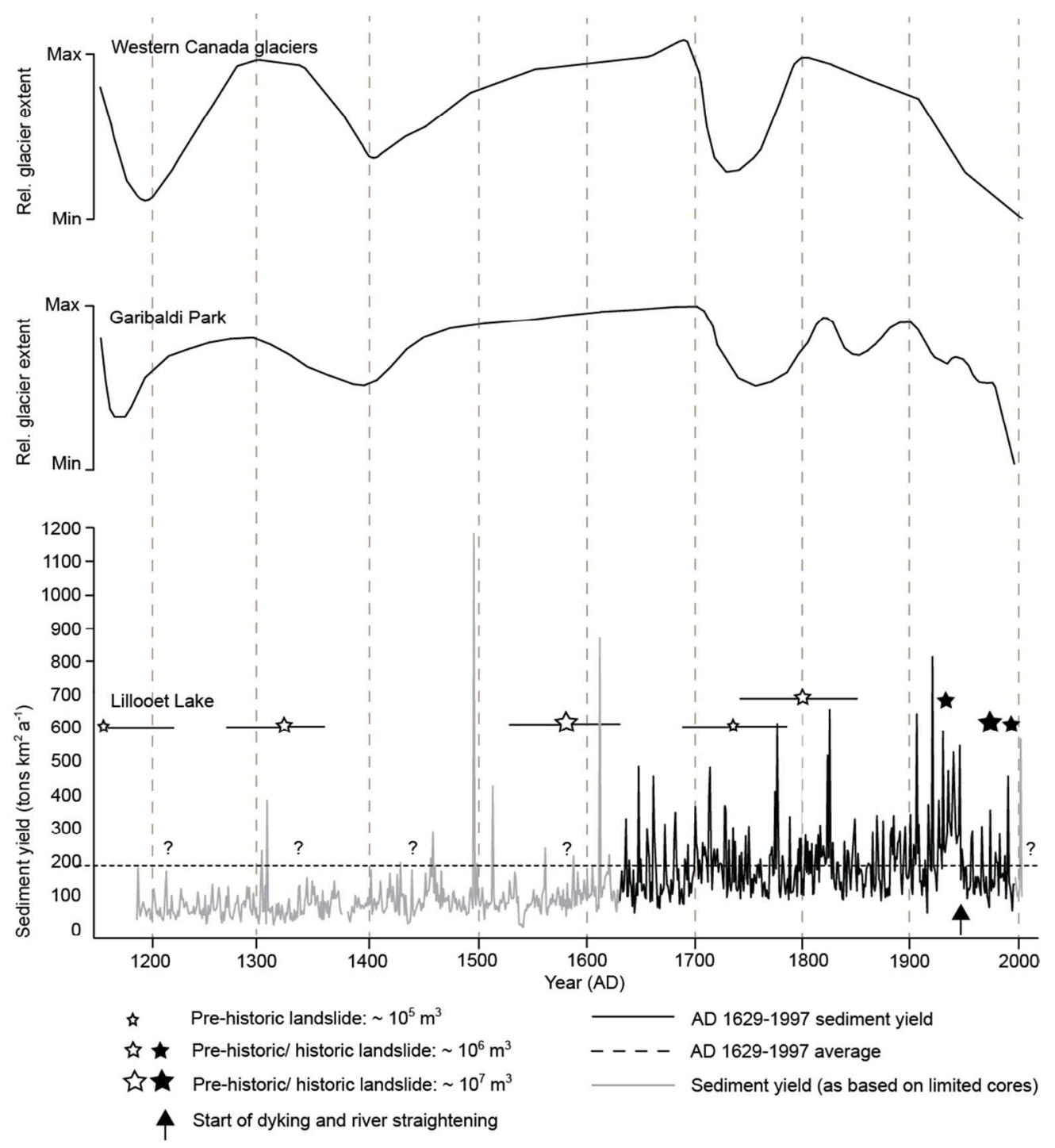

Sediment yield and glacial history 
a

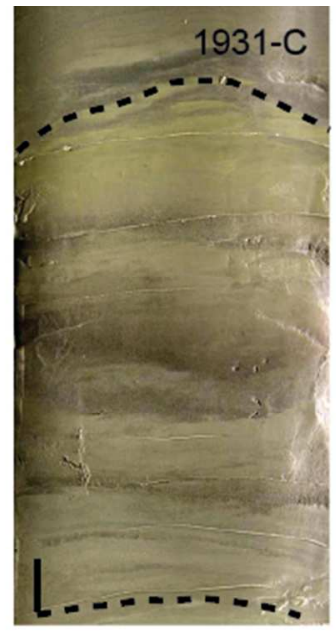

b

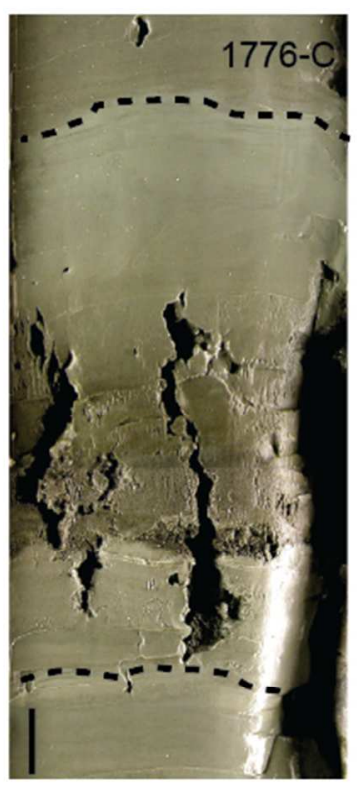

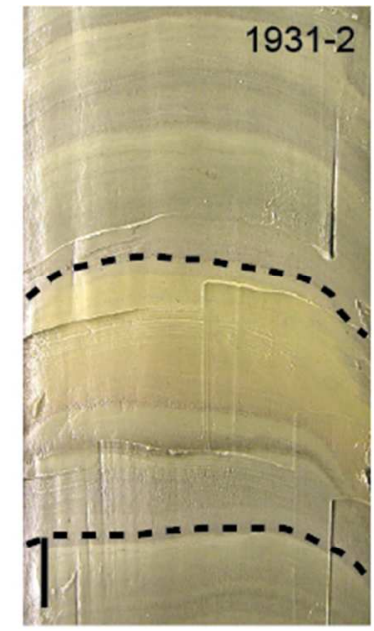
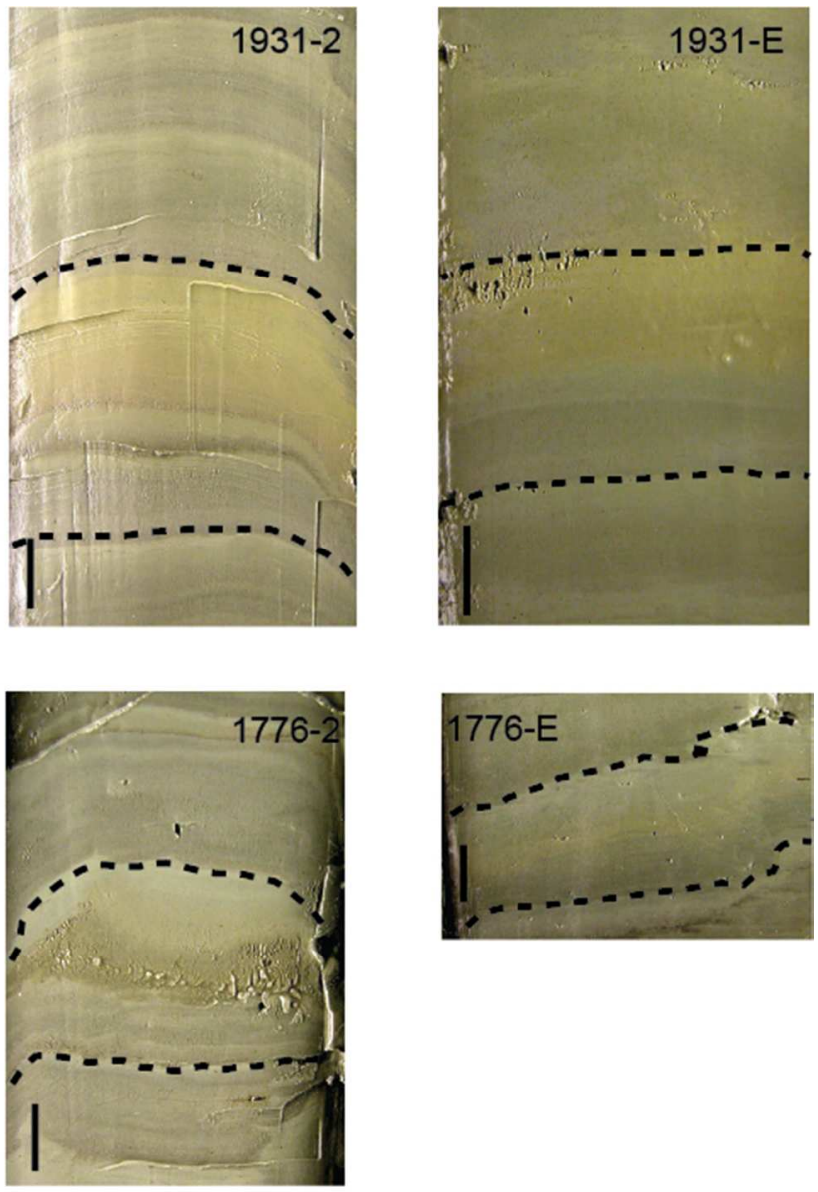

Varve pictures 


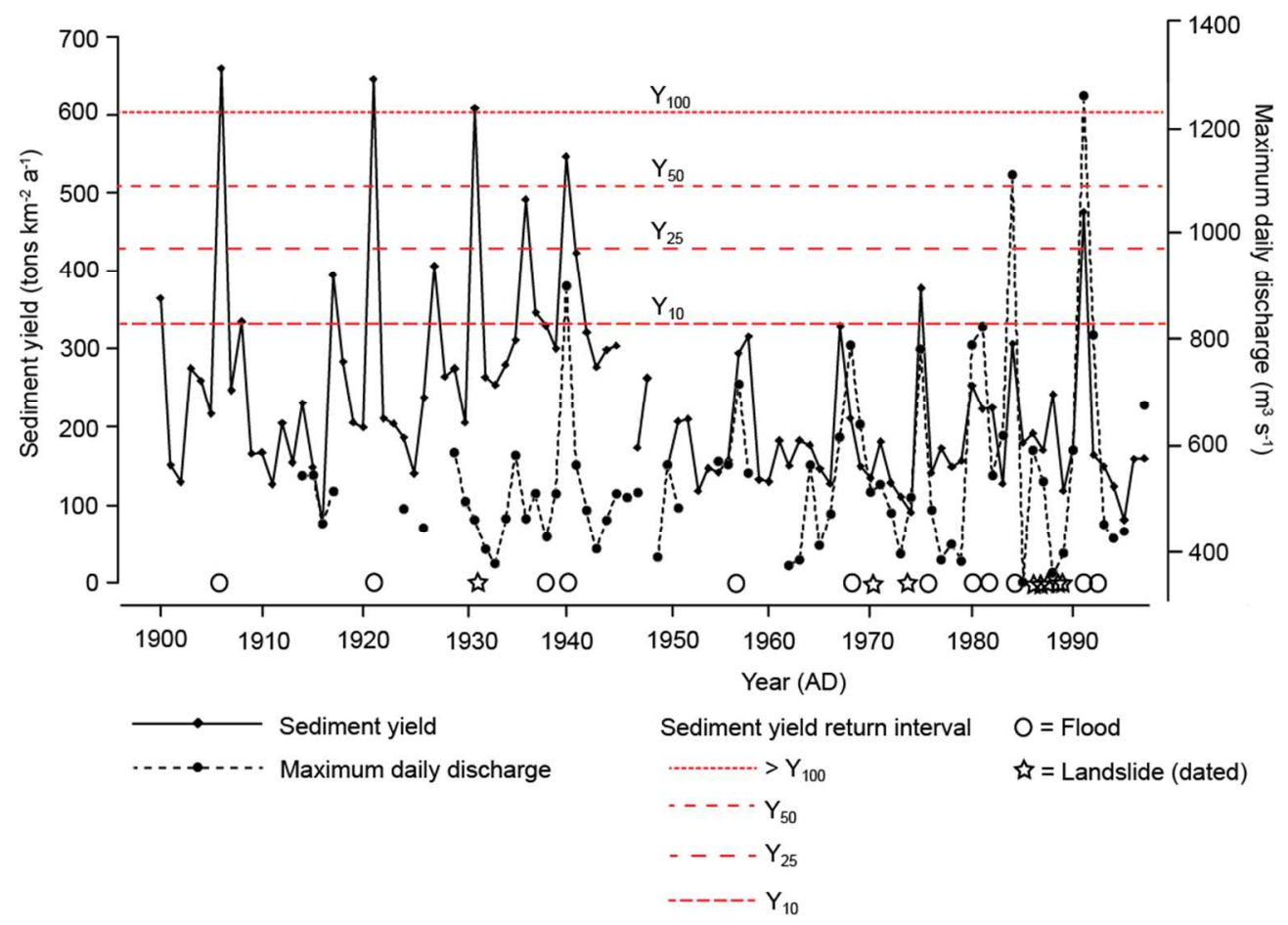

Sediment yield 20th century 